\title{
Synthesis and reactivity of remarkably stable and nucleophilic hydroxide-bridged dimetallic nickel NHC complexes
}

\author{
Simone Bertini, ${ }^{\mathrm{a}}$ Martin Albrecht*,a \\ ${ }^{a}$ Department of Chemistry \& Biochemistry, University of Bern, Freiestr 3, CH-3012 Bern, \\ Switzerland \\ E-mail: martin.albrecht@dcb.unibe.ch
}

\begin{abstract}
A novel class of dicationic homodimetallic nickel(II) NHC complexes $\left[(\mathrm{NHC})_{2} \mathrm{Ni}(\mu-\mathrm{OH})_{2} \mathrm{Ni}(\mathrm{NHC})_{2}\right]^{2+}$ was synthesized starting from nickel acetate as metal precursor. Symmetrically substituted $\mathrm{N}$-alkyl (methyl, isopropyl and isobutyl) imidazolylidene (imi) as well as N1-methyl, phenyl, mesityl and butyl substituted triazolylidene (trz) ligands were coordinated to the metal center through $\mathrm{NaH}$-mediated metalation. Reaction of these bimetallic complexes with $\mathrm{CH}_{3}{ }^{+}$as electrophile (MeOTf) induced alkylation of the bridging hydroxid ligands and afforded new alkoxy-bridged complexes $\left[(\mathrm{NHC})_{2} \mathrm{Ni}(\mu-\right.$ $\left.\mathrm{OMe})_{2} \mathrm{Ni}(\mathrm{NHC})_{2}\right]^{2+}$. In contrast, reactions of $\left[(\mathrm{imi})_{2} \mathrm{Ni}(\mu-\mathrm{OH})_{2} \mathrm{Ni}(\mathrm{imi})_{2}\right]^{2+}$ with $\mathrm{H}^{+}$as electrophile (mild acids with $\mathrm{p} K_{\mathrm{a}}>6$ ) lead to cleavage of the dimeric structure and formation of mononuclear complexes $\left[\mathrm{Ni}(\mathrm{X})_{2}(\mathrm{imi})_{2}\right]$. Conversely, no reaction occurs for the triazolylidene analogues $\left[(\operatorname{trz})_{2} \mathrm{Ni}(\mu-\mathrm{OH})_{2} \mathrm{Ni}(\operatorname{trz})_{2}\right]^{2+}$, indicating different robustness of the dimetallic core to acidic media. Only exposure to stronger acids $\left(\mathrm{p} K_{\mathrm{a}}<5\right)$ induced dimer cleavage for the trz complexes and gave either the corresponding triazolium salt, or in the presence of a coordinating anion, monomeric species $\left[\mathrm{Ni}(\mathrm{X})_{2}(\operatorname{trz})_{2}\right]$ with $\mathrm{X}=\mathrm{I}$, OAc or $(\mathrm{X})_{2}=\mathrm{CO}_{3}$. All complexes were inert towards Lewis and Brønsted bases such as $\mathrm{NEt}_{3}$ or $\mathrm{NaOMe}$. These results reveal a remarkable robustness of the acidic $\mathrm{Ni}$ centers and the $\mathrm{OH}$ protons towards bases, and contrast the distinct reactivity of the Lewis basic oxygen donor sites, which are more reactive than the carbene towards electrophiles.
\end{abstract}

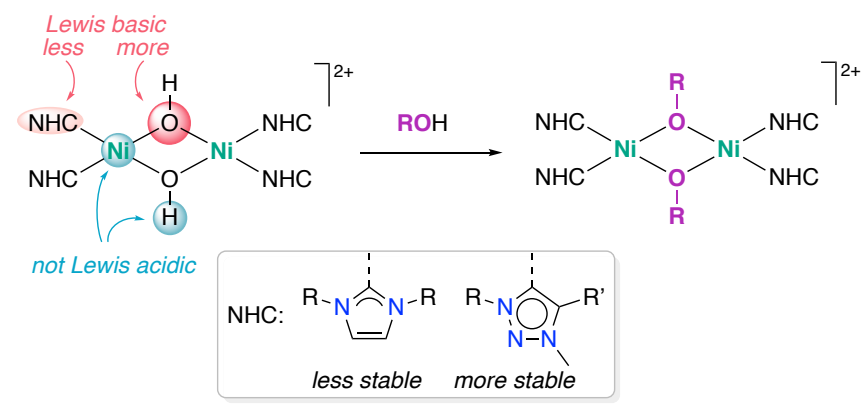




\section{Introduction}

The synthesis of well-defined dimetallic species based on Earth-abundant metals has long been a challenging task. The instability of the resulting complexes and difficulties in characterization often complicated the study of such systems. ${ }^{1,2}$ In order to accomplish this goal, various ligands and synthetic approaches have been explored, resulting in complexes with great activity in diverse catalytic applications, such as carbonyl reduction, ${ }^{3}$ oxygen activation ${ }^{4}$ and $\mathrm{C}-\mathrm{C}$ and $\mathrm{C}-$ $\mathrm{X}$ coupling reactions..$^{5-9} \mathrm{~N}$-heterocyclic carbene (NHC) ligands have become particularly interesting as scaffold for such bimetallic systems due to their electronic flexibility, strong donor ability, and their compatibility with a wide range of transition metals. ${ }^{10-15}$ Exploration of the coordination of imidazolylidene (imi) ligands to nickel afforded several well-defined homodimetallic NHC-supported complexes with the nickel centers bridged by N, P or O donors, amongst others. ${ }^{16-20}$ Oxo-bridged nickel species containing the Ni-O-Ni motif have some peculiar features, such as a relatively high stability of the resulting complexes imparted by strong Ni-O bonds and a pronounced nucleophilicity of the bridging oxygen. ${ }^{21,22}$ These two aspects are considered key for their high activity as catalysts, for example for mimicking enzymatic urease reactivity and for the fixation of atmospheric $\mathrm{CO}_{2}{ }^{16,23}$ Specifically, the enzymatic pocket of urease from "bacillus pasteurii" features a $\mathrm{Ni}-\mathrm{O}(\mathrm{H})-\mathrm{Ni}$ motif as active site that enables the bridging hydroxide ion to act as a nucleophile for attacking the metalbound urea. ${ }^{24}$

From a synthetic perspective, the bridging hydroxide ligand provides opportunities for further functionalization directly at the metal coordination sphere via simple Lewis acid-base reactions. However, hydroxy-bridged homodimetallic nickel species based on NHC ligands have not been investigated extensively; a single report details the synthesis and isolation of a well-defined homodimetallic OH-bridged imidazolylidene supported species. ${ }^{25}$ Here we report on a versatile synthetic approach to a family of well-defined OH-bridged dimetallic nickel complexes supported by NHC ligands and their distinct reactivity patterns towards electrophiles and nucleophiles.

\section{Result and discussion}

The new homodimetallic nickel(II) complexes 2a-c supported by NHC ligands were synthesized upon reaction of readily available imidazolium salts, nickel acetate, and $\mathrm{NaH}$ in dry THF under inert conditions (Scheme 1). The procedure was tolerant to differently substituted imidazolium salts with diverse counterions $\left(\mathrm{X}=\mathrm{I}, \mathrm{PF}_{6}\right)$, and the complexes were bench-stable and isolated in good yields (around $40 \%$ based on the imidazolium salt). 

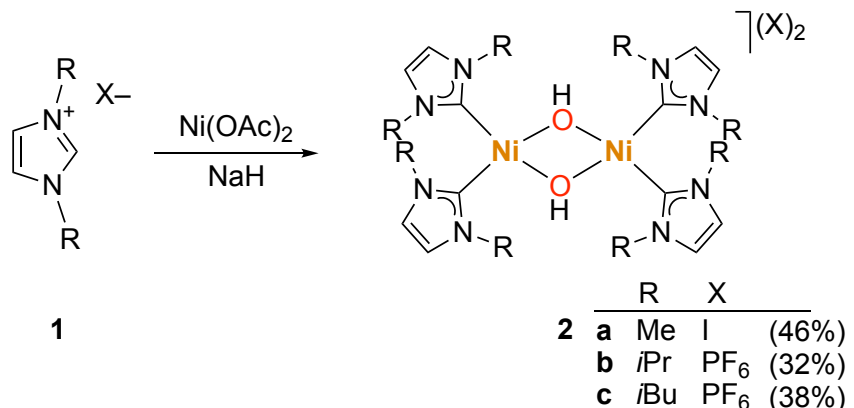

Scheme 1. Synthesis of homodimetallic Ni(II) NHC complexes $\mathbf{2 a - c . ~}$

Mass and elemental analysis confirmed the dimetallic nature of the three new species. NMR characterization was possible as the resulting complexes were diamagnetic. The complexes display $\mathrm{C}_{2 v}$ symmetry in solution as deduced from the equivalence of all four NHC ligands in each complex, showing one single set of signals for protons and carbons. A distinct feature of complexes $2 \mathbf{2 a}-\mathbf{c}$ is the high field $\mathrm{Ni}-\mathrm{OH}$ resonance in the ${ }^{1} \mathrm{H}$ NMR spectrum around $\delta_{\mathrm{H}}=-3$, consistent with considerable nucleophilicity of the bridging hydroxide groups. ${ }^{22,26-29}$ The chemical shift is dependent on the substitution pattern on the NHC ligand $\left(\delta_{\mathrm{H}}=-2.63\right.$ for $\mathrm{R}=$ $\mathrm{Me} ;-3.16$ for $i \mathrm{Pr} ;-3.92$ for $i \mathrm{Bu}$ ), which strongly suggests that these substituents affect the electronic configuration of the dimetallic core. The ${ }^{13} \mathrm{C}$ NMR resonances for the carbenic carbons are slightly different among the Ni-NHC complexes, increasing from 153.8 to 158.3 ppm in the order $i \operatorname{Pr}<i \mathrm{Bu}<\mathrm{Me}$.

Crystals suitable for X-ray diffraction analysis were grown for all three complexes 2a-c. The molecular structures reveal two metal centers each adopting a distorted square planar geometry (Fig. 1). The two metal coordination planes are almost co-planar, resulting in a wide open-book conformation $\left(\theta=136-170^{\circ}\right.$; Table 1$)$. The relative orientation of the two Ni coordination planes is substantially affected by the ligand substitution pattern, suggesting a major role of the ligand in tailoring the overall geometry of the dimetallic species. The dihedral angle $\theta$ follows the order $\mathbf{2} \mathbf{a}(\mathrm{R}=\mathrm{Me})<\mathbf{2} \mathbf{c}(i \mathrm{Bu})<\mathbf{2} \mathbf{b}(i \mathrm{Pr})$ and increases from $136^{\circ}$ to $153^{\circ}$ and $170^{\circ}$, indicating that bulkier $\mathrm{N}$-substituents on the NHC ligand induce a higher coplanarity of the two $\mathrm{Ni}$ coordination planes. A possible rationale for this behavior is the steric interference of the imidazolylidene substituents, which is minimized with a larger dihedral angle for large substituents. In support of this notion, also the $\mathrm{C}_{\mathrm{Im}}-\mathrm{Ni}-\mathrm{C}_{\mathrm{Im}}$ angle increases with bulkier $\mathrm{NHC}$ substituents from $92^{\circ}$ up to $97^{\circ}$. As a consequence of the varying dihedral angle, also the intermetallic Ni...Ni distance increases along this series from $2.72 \AA$ (2a) to $2.82 \AA$ (2c) and $2.88 \AA$ (2b). The $\mathrm{Ni}-\mathrm{O}$ and $\mathrm{Ni}-\mathrm{C}$ bond lengths are between 1.87 and $1.89 \AA$, well within the range observed for related nickel carbene complexes. ${ }^{17,30} \mathrm{Also}$, the $\mathrm{O}-\mathrm{Ni}-\mathrm{O}$ bond angle is only marginally affected by ligand tailoring. 


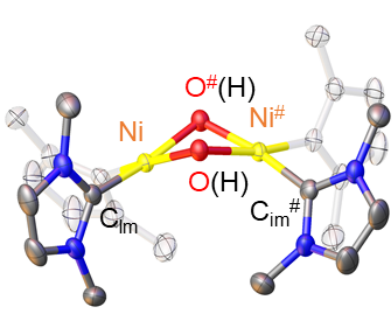

2a

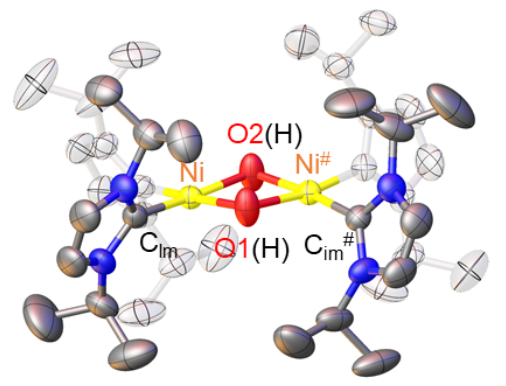

2b

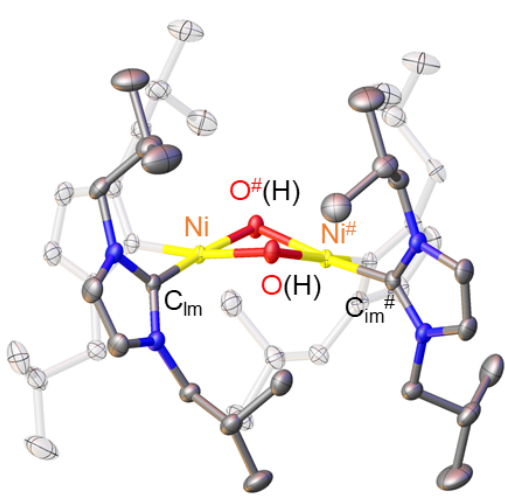

2c

Figure 1. ORTEP diagram of Ni complexes $\mathbf{2 a}-\mathbf{c}$ (50\% probability level thermal ellipsoids; hydrogen atoms, non-coordinating iodide anions in $\mathbf{2 a}$, and $\mathrm{PF}_{6}{ }^{-}$anions in $\mathbf{2 b}$ and $\mathbf{2} \mathbf{c}$ as well as co-crystallized water molecule for $\mathbf{2 a}$ omitted for clarity). Symmetry related atoms are marked with \# $(1-\mathrm{x},+\mathrm{y}, 3 / 2-\mathrm{z}$ for $\mathbf{2 a}$, and $1-\mathrm{x},+\mathrm{y}, 1 / 2-\mathrm{z}$ for $\mathbf{2 b}$ and $\mathbf{2} \mathbf{c}$ ).

Table 1. Selected bond lengths $(\AA)$ and angles (deg) of complexes $\mathbf{2 a}-\mathbf{c} .^{a}$

\begin{tabular}{llll}
\hline & $\mathbf{2 a}$ & $\mathbf{2 b}$ & $\mathbf{2 c}$ \\
\hline $\mathrm{Ni} . . \mathrm{Ni}$ & $2.7245(6)$ & $2.8824(7)$ & $2.8182(3)$ \\
$\mathrm{Ni}-\mathrm{O}$ & $1.889(4)$ & $1.874(3)$ & $1.882(2)$ \\
$\mathrm{Ni}-\mathrm{C}_{\mathrm{Im}}$ & $1.870(1)$ & $1.884(2)$ & $1.877(6)$ \\
$\mathrm{C}_{\mathrm{Im}}-\mathrm{Ni}-\mathrm{C}_{\mathrm{Im}}$ & $91.74(1)$ & $96.90(1)$ & $94.92(6)$ \\
$\mathrm{O}-\mathrm{Ni}-\mathrm{O}$ & $78.00(9)$ & $79.48(1)$ & $77.99(5)$ \\
$\mathrm{Ni}-\mathrm{O}-\mathrm{Ni}$ & $92.30(7)$ & $100.5(2)$ & $96.94(4)$ \\
$\theta^{b}$ & 135.93 & 169.82 & 152.07
\end{tabular}

${ }^{a}$ average of two values; ${ }^{b}$ dihedral angle of the two Ni coordination planes defined by Ni, the two oxygen and the two carbon nuclei for each metal center.

Intrigued by the remarkable nucleophilicity of the bridging $\mathrm{OH}$ groups deduced from the NMR chemical shifts, the reactivity of the complexes towards protons as electrophiles was explored. Thus, reaction of complex $\mathbf{2 a}$ with an excess of $\mathrm{D}_{2} \mathrm{O}$ induced rapid deuteration of the bridging hydroxy group and afforded complex $\mathbf{2} \mathbf{a}-\mathbf{D}_{\mathbf{2}}$, indicated by the essentially instantaneous disappearance of the high-field resonance at $-2.6 \mathrm{ppm}$ while all other signals remained unchanged (Figure S20). Formation of $\mathbf{2} \mathbf{a}-\mathbf{D}_{\mathbf{2}}$ may result from either direct H/D exchange at 
the bridging oxygen nucleus or by $\mathrm{OH} / \mathrm{OD}$ exchange at the nickel center (vide infra). Support of the latter process was obtained from similar exposure of complexes 2a-c to $\mathrm{MeOH}$ in $\mathrm{CH}_{3} \mathrm{CN}$, which led to a ligand metathesis reaction and afforded the OMe-bridged dinuclear complexes 3a-c through coordination of two bridging alkoxides to the $\mathrm{Ni}_{2}$ core (Scheme 2, $\mathrm{X}$ $=\mathrm{I}, \mathrm{PF}_{6}$ ). The reaction was followed by ${ }^{1} \mathrm{H}$ NMR spectroscopy with hexamethylbenzene as internal standard, which showed a gradual decrease in intensity of the $\mathrm{OH}$ resonance and a concomitant shift of the $\mathrm{NCH}_{3}$ resonance from 4.13 to 4.21 for complex $2 \mathbf{a}$ and of the $\mathrm{NCH}_{2}$ resonances from around 6.3 and $4.8 \mathrm{ppm}$ to $5.5 \mathrm{ppm}$ for complexes $\mathbf{2 b}$ and $\mathbf{2 c}$ respectively. The characterization of the resulting species directly in the reaction medium by ${ }^{1} \mathrm{H}$ NMR was hampered by the presence of the excess $\mathrm{MeOH}$, however heteronuclear ${ }^{1} \mathrm{H} /{ }^{13} \mathrm{C}$ shift correlation spectroscopy (HSQC) indicated a correlation between the proton at $\delta=3.2 \mathrm{ppm}$ and carbon around $\delta=57( \pm 3) \mathrm{ppm}$ which were assigned to the bridging $\mathrm{OCH}_{3}$ units. Time-dependent NMR monitoring showed quantitative conversions for complexes $\mathbf{2 a}$ and $\mathbf{2} \mathbf{b}$ in less than $5 \mathrm{~min}$, while the exchange was only partial for complex $\mathbf{2 c}$ and did not increase even after extended reaction times (around 30\% by NMR analysis within $16 \mathrm{~h}$; Fig. S22). Interestingly, the process is reversible as all attempts to isolate complexes $\mathbf{3 a}-\mathbf{c}$ led to quantitative regeneration of species 2a-c. Reaction of complexes $\mathbf{2 a - c}$ with $\mathrm{NaOMe}$ did not result is any formation of products $\mathbf{3 a}-$ c, suggesting that protonation of the bridging $\mathrm{OH}$ units is key to this ligand exchange.

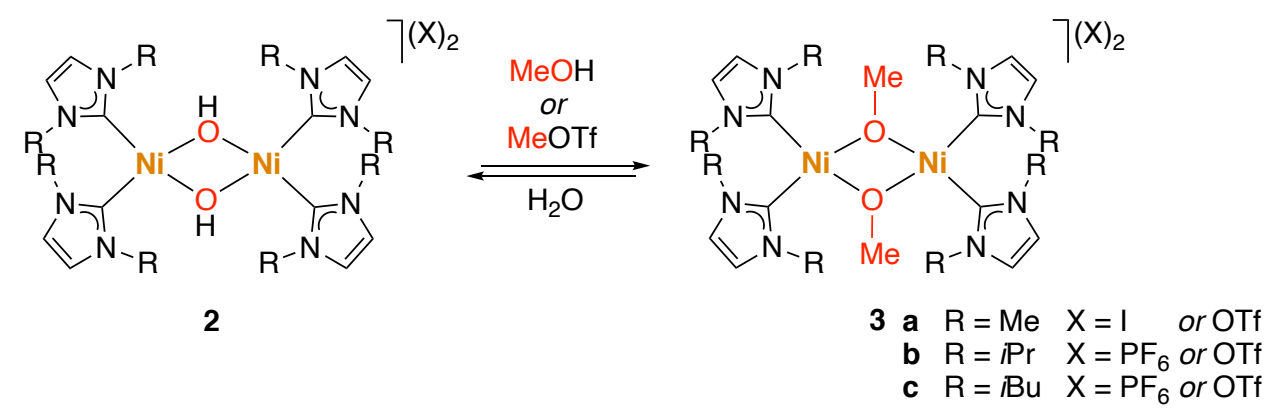

Scheme 2. Synthesis of dinuclear methoxy-bridged complexes 3a-c.

Complexes 2a-c were therefore reacted with electrophilic methylation reagents rather than proton source in order to access the same coordination motif in a controlled manner. While no reaction was observed with MeI, complexes $\mathbf{2 a}-\mathbf{c}$ readily yielded complexes $\mathbf{3 a}-\mathbf{c}$ when treated with MeOTf in MeCN at room temperature (Scheme 2, X = OTf, Fig. S21), suggesting an attractive pathway for the functionalization of the $\mathrm{OH}$ groups in situ. The NMR data of complexes 3a-c are not affected by the nature of the non-coordinating anion. They suggest a $\mathrm{C}_{2 v}$ symmetry for the complex, with all four NHC ligands magnetically equivalent. The bridging methoxy unit appeared as a characteristic resonance around $3.3 \mathrm{ppm}$ and $57 \mathrm{ppm}$ in ${ }^{1} \mathrm{H}$ and ${ }^{13} \mathrm{C}$ 
NMR spectroscopy, respectively, confirming the in situ analysis from the reaction with $\mathrm{MeOH}$. Bonding of the alkoxide unit also induces a substantial $10 \mathrm{ppm}$ upfield shift of the ${ }^{13} \mathrm{C} N \mathrm{NM}$ resonances for the carbene carbons compared to the $\mathrm{OH}$ bridged analogues $\left(\delta_{\mathrm{C}}=144( \pm 2)\right.$ for 3a-c $v s$ 155( \pm 3$)$ for $\mathbf{2 a}-\mathbf{c})$.

Crystals suitable for X-ray diffraction analysis were grown from a methanol solution of complexes 3a-c. The molecular structures show full retention of the dimetallic scaffold (Fig. 2). Of interest, crystals grown from the reaction of complex $\mathbf{3 c}$ with methanol showed partial exchange of the bridging ligand, displaying the presence of both complexes $2 \mathbf{c}$ and $\mathbf{3 c}$ in the same single crystal. Refinement of the occupancy of the $\mathrm{CH}_{3}$ group indicated $32 \%$ conversion, confirming the conclusions deduced from NMR analysis. The only partial conversion suggests a decreased nucleophilicity for the bridging units of the dimetallic core imparted by the $i \mathrm{Bu}$ substituted imidazolylidene ligand when compared to the other NHC ligands. While most bond lengths and angles in the structures of the $\mu-\mathrm{OMe}$ complexes 3a-c, are similar to those of the $\mu-\mathrm{OH}$ complexes 2a-c (Table 2), it is interesting to note that the dihedral angle $\theta$ of the metal coordination planes follows an opposite trend. The planes are essentially coplanar in complex 3a, yet more inclined in complexes $\mathbf{3 b}$ and $\mathbf{3 c}\left(\theta=147^{\circ}\right.$ and $153^{\circ}$, respectively), presumably as a consequence of the increased steric demand of the $\mathrm{OCH}_{3}$ bridge compared to $\mathrm{OH}$.

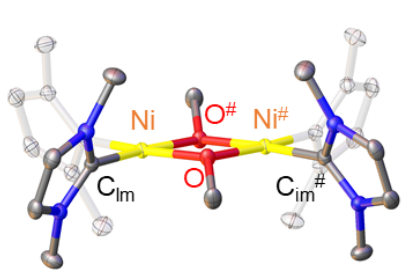

3a

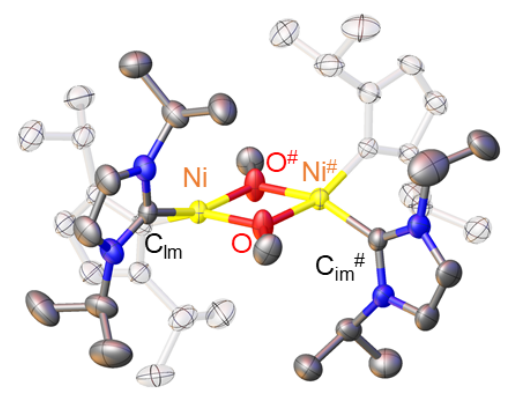

3b

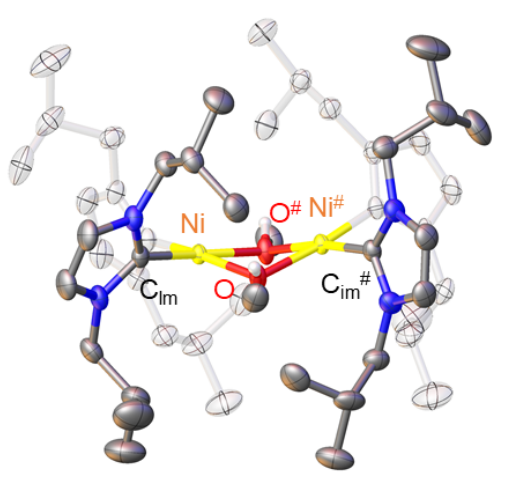

$3 c$

Figure 2. ORTEP diagram of Ni complexes $\mathbf{3 a}-\mathbf{c}$ ( $50 \%$ probability level thermal ellipsoids; hydrogen atoms, non-coordinating iodide anions in $\mathbf{3} \mathbf{a}$ and $\mathrm{PF}_{6}{ }^{-}$in $\mathbf{3 b}$ and $\mathbf{3 c}$, and co-crystallized $\mathrm{MeOH}$ molecules for 3a omitted for clarity). For $\mathbf{3} \mathbf{c}$ refinement of the occupancy of the $\mathrm{CH}_{3}$ group indicated $32 \%$ of $\mathbf{3} \mathbf{c}$ and $68 \% 2$ c. Symmetry related atoms are marked with $\#(1-x,+y, 3 / 2-z$ for $3 a, 1 / 2-x, 1 / 2-y,+z$ for $\mathbf{3 b}$, $1-\mathrm{x},+\mathrm{y}, 3 / 2-\mathrm{z}$ for $3 \mathrm{c})$. 
Table 2. Selected bond lengths $(\AA)$ and angles (deg) of complex $\mathbf{3 a}-\mathbf{c}^{a}$

\begin{tabular}{llll}
\hline & 3a & 3b & 3c \\
\hline $\mathrm{Ni} \ldots \mathrm{Ni}$ & $2.8774(6)$ & $2.8937(8)$ & $2.8371(5)$ \\
$\mathrm{Ni}-\mathrm{O}$ & $1.891(1)$ & $1.887(2)$ & $1.8853(3)$ \\
$\mathrm{Ni}-\mathrm{C}_{\mathrm{Im}}$ & $1.862(2)$ & $1.862(3)$ & $1.876(5)$ \\
$\mathrm{C}-\mathrm{O}$ & $1.418(3)$ & $1.407(6)$ & $1.437(8)$ \\
$\mathrm{C}_{\mathrm{Im}}-\mathrm{Ni}-\mathrm{C}_{\mathrm{Im}}$ & $93.50(1)$ & $93.56(1)$ & $94.65(9)$ \\
$\mathrm{O}-\mathrm{Ni}-\mathrm{O}$ & $80.94(7)$ & $79.80(1)$ & $78.24(7)$ \\
$\mathrm{Ni}-\mathrm{O}-\mathrm{Ni}$ & $99.06(7)$ & $100.09(9)$ & $97.60(6)$ \\
$\theta^{b}$ & 180.00 & 146.92 & 153.29 \\
\hline average of two values; ${ }^{b}$ dihedral angle of the two Ni coordination planes defined by Ni, the two oxygen \\
nd the two carbon nuclei for each metal center.
\end{tabular}

Reactivity of complex 2a with different electrophiles and nucleophiles. Similar to the reaction with $\mathrm{MeOH}\left(\mathrm{p} K_{\mathrm{a}}=15.5\right)$, addition of an excess $\mathrm{EtOH}\left(\mathrm{p} K_{\mathrm{a}}=15.9\right)$ to complex 2a in $\mathrm{MeCN}$ afforded the novel ethoxy-bridged bimetallic complex 4 (Fig. 3). The reaction was followed by ${ }^{1} \mathrm{H}$ NMR measurements, which showed an immediate decrease in intensity of the $\mathrm{OH}$ resonance and a concomitant shift of the $\mathrm{NCH}_{3}$ resonance from 4.13 to $4.24 \mathrm{ppm}$. In addition, two new resonances at 3.66 and $1.62 \mathrm{ppm}$ were assigned to the $\mathrm{OCH}_{2} \mathrm{CH}_{3}$ protons of the bridging ethoxide ligand. The complex was unstable even at low temperatures $\left(-35^{\circ} \mathrm{C}\right)$ in $\mathrm{MeCN}$ solution as indicated by the formation of a precipitate as well as the erosion of the integral signals relative to the internal standard (Fig. S23), which hampered full characterization. Crystals suitable for diffraction studies were obtained from an EtOH solution at low temperature, though their manipulation was complicated by their low stability in air and at room temperature. Moreover, the structure revealed considerable disorder of the bridging ligands, which prevents a detailed discussion. Nonetheless, the molecular structure fully confirmed the connectivity pattern of complex 4 (Fig. 3). 


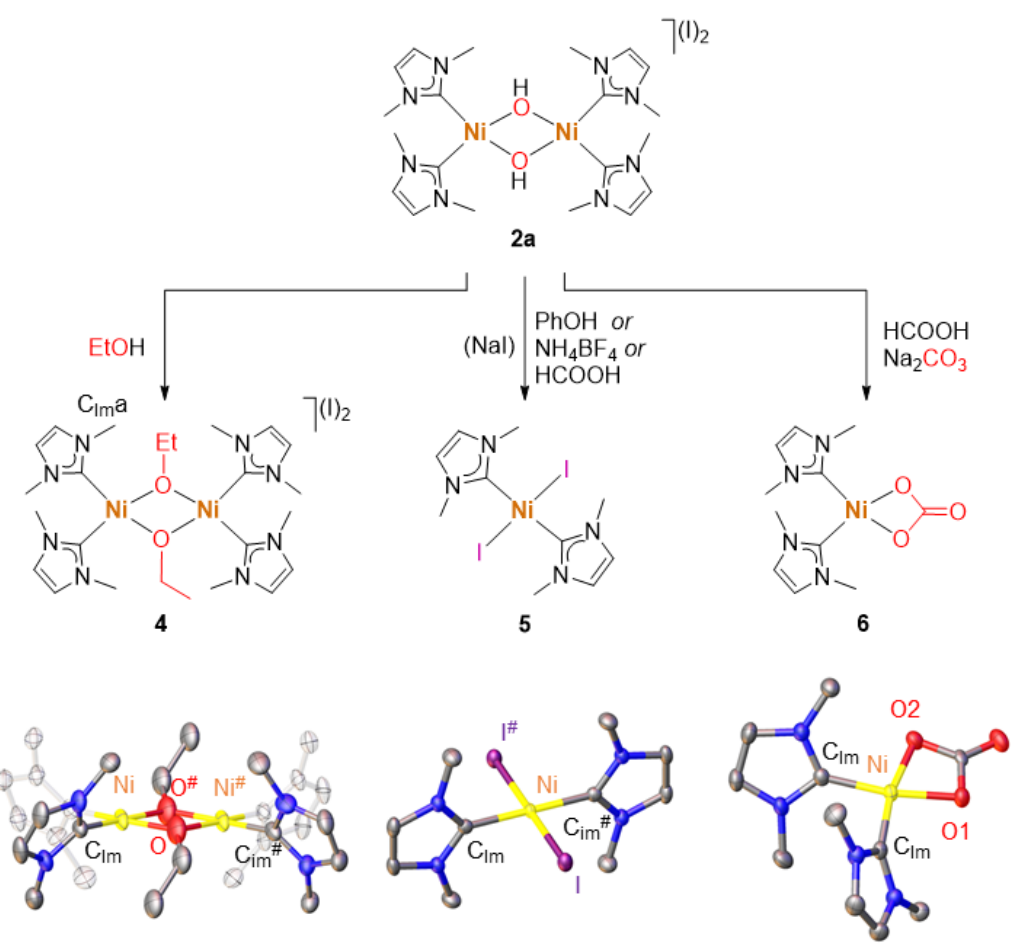

Figure 3. Synthesis and ORTEP diagrams of Ni complexes 4-6 (40\% probability for 4 and $50 \%$ probability level thermal ellipsoids for $\mathbf{5}$ and $\mathbf{6}$; hydrogen atoms, non-coordinating iodide and cocrystallized EtOH molecule for $\mathbf{4}$ omitted for clarity). Symmetry related atoms are marked with \# (1-x, $1-\mathrm{y}, 2-\mathrm{z}$ for $\mathbf{4}, 1-\mathrm{x}, 1-\mathrm{y}, 1-\mathrm{z}$ for $\mathbf{5})$.

Stronger acids were detrimental to the stability of the $\mathrm{Ni}_{2}$ core. For example, addition of phenol $\left(\mathrm{p} K_{\mathrm{a}}=10\right), \mathrm{NH}_{4} \mathrm{BF}_{4}\left(\mathrm{p} K_{\mathrm{a}}=9.2\right)$, or formic acid $\left(\mathrm{p} K_{\mathrm{a}}=3.75\right)$ to complex 2a induced cleavage of the dimeric structure and formation of the known ${ }^{31,32}$ neutral bis(carbene) nickel(II) complex 5 in about 50\% isolated yield (Fig. 5). Reaction of complex 2a with $\mathrm{CO}_{2}$ in $\mathrm{MeCN}$ solution also led to the formation of monomeric complex $\mathbf{5}$, most likely due to the acidity of the media upon dissolution of $\mathrm{CO}_{2}$. Yields of complex 5 became essentially quantitative when the reaction with formic acid was carried out in the presence of NaI, indicating that the monometallic complex is the thermodynamically favored product upon protonation of the dimetallic core, and that the iodide counterion acts as limiting reagent in the absence of NaI. Performing the reaction in the presence of sodium carbonate rather than iodide resulted in the instantaneous and quantitative formation of the carbonate complex $\mathbf{6}$. No reaction occurred when complex $2 \mathbf{a}$ was exposed to 3 eq. of $\mathrm{EtNH}_{2}, \mathrm{NEt}_{3}$, or sodium carbonate, indicating a high robustness towards bases.

In an attempt to investigate whether the coordinating ability of the anion is critical for dimer cleavage, the iodide counterions in complex $\mathbf{2 a}$ were exchanged with $\mathrm{BPh}_{4}{ }^{-}$affording complex $\mathbf{2 a}\left(\mathbf{B P h}_{4}\right)$. Characterization of this species by NMR spectroscopy indicates no electronic perturbation of the dimetallic scaffold upon counterion metathesis $\left(\delta_{\mathrm{OH}}-2.61\right.$ and -2.56 for complexes 2a(BPh$)$ and 2a, respectively). Exposure of complex $\mathbf{2 a}\left(\mathbf{B P h} \mathbf{h}_{4}\right)$ to mild acids such 
as $\mathrm{NH}_{4} \mathrm{BF}_{4}$ or formic acid led to a breakdown of the dimetallic structure and gave the imidazolium salt 1a quantitatively in less than 5 min, indicating that the Brønsted acidity rather than anion coordination induce dimer cleavage.

Based on the results of these reactivity studies, some general conclusions concerning the properties of the dinickel complexes $\left[(\mathrm{imi})_{2} \mathrm{Ni}(\mu-\mathrm{OH})_{2} \mathrm{Ni}(\mathrm{imi})_{2}\right]$ can be drawn (imi $=$ imidazolylidene). Both Lewis-acidic units of the dinuclear complex, i.e. the nickel(II) centers and the protons of the hydroxid bridge, are remarkable stable under alkaline conditions $\left(\mathrm{EtNH}_{2}\right.$, $\mathrm{NEt}_{3}, \mathrm{NaOMe}$, or $\mathrm{Na}_{2} \mathrm{CO}_{3}$ ), which reveals a low electrophilicity of both these sites. Reactions with electrophiles suggest that the bridging oxygen is the more reactive basic site than the carbene. Oxygen protonation is surmised to induce the reversible methathesis of the hydroxide with an alkoxide ligand (formation of $\left[(\mathrm{imi})_{2} \mathrm{Ni}(\mu-\mathrm{OR})_{2} \mathrm{Ni}(\mathrm{imi})_{2}\right]$. These species are also obtained by direct alkylation with electrophilic methylation reagents, which occurs selectively at the $\mathrm{O}$ nucleophilic site. More acidic reagents presumably lead to similar $\mu-\mathrm{OH}$ protonation and metathesis with non-bridging anions to yield monomeric $\left[\mathrm{Ni}(\mathrm{NHC})_{2} \mathrm{X}_{2}\right]$ complexes with $\mathrm{X}=\mathrm{I}$ or $\mathrm{X}_{2}=\mathrm{CO}_{3}$, again suggesting that protonation preferentially takes place at the bridging $\mathrm{OH}$ and not at the carbene. Only in the absence of coordinating anions, quantitative conversion to imidazolium salts takes place, indicating that the carbenic carbon is also protonated under these conditions. We suppose that the oxygen of the bridging ligand of the dimetallic complex reacts first with one equivalent of acid, which leads to the cleavage of the dimer and concomitant formation of a solvento intermediate with a more nucleophilic carbene carbon that is susceptible to protonation.

\section{Synthesis of the triazolylidene analogues}

Since the reactivity of the bridging hydroxy group is directly influenced by the carbene ligand ( $c f$ formation of $\mathbf{3 a}-\mathbf{c}$ ), exchange of the imidazolylidene scaffold by 1,2,3-triazole-derived carbenes was expected to have a further impact on the reactivity, since these triazolylidene (trz) ligands are stronger donors and exert a higher trans effect. ${ }^{15}$ Reaction of the triazolium salts containing $\mathrm{N}$-alkyl- or $\mathrm{N}$-aryl substituents with nickel acetate under conditions identical to those applied for the formation of complexes 2a-c afforded the corresponding dinuclear triazolylidene nickel(II) complexes 8a-d with bridging $\mathrm{OH}$ groups in moderate $40 \%$ yields (Scheme 3). This outcome indicates the usefulness of the nickelation protocol with different subclasses of NHC ligands. The dimetallic structure of complexes 8a-d was confirmed by MS, and NMR analysis revealed similar features as discussed for complexes $\mathbf{2 a - c}$. The bridging hydroxy groups appear at $\delta_{\mathrm{H}}=-4.2( \pm 1.0)$, suggesting a stronger nucleophilic character of the 
bridging $\mathrm{OH}$ ligand than in the imidazolylidene analogues with $\delta_{\mathrm{H}}=-3.2( \pm 0.6)$. Higher electron density at hydrogen may be directly related to the enhanced $\sigma$ donor properties of the triazolylidene to the metal center compared to imidazolylidene. Notably, the chemical shift of the $\mathrm{OH}$ group in complexes 8a-d does not correlate with the anticipated electronic impact of the triazolylidene $N$-substituents, possibly due to steric constraints imposed by the dimetallic arrangement. The carbenic carbons of complexes 8a-d appear between 148.2 and 146.4 ppm in the ${ }^{13} \mathrm{C}$ NMR spectra.
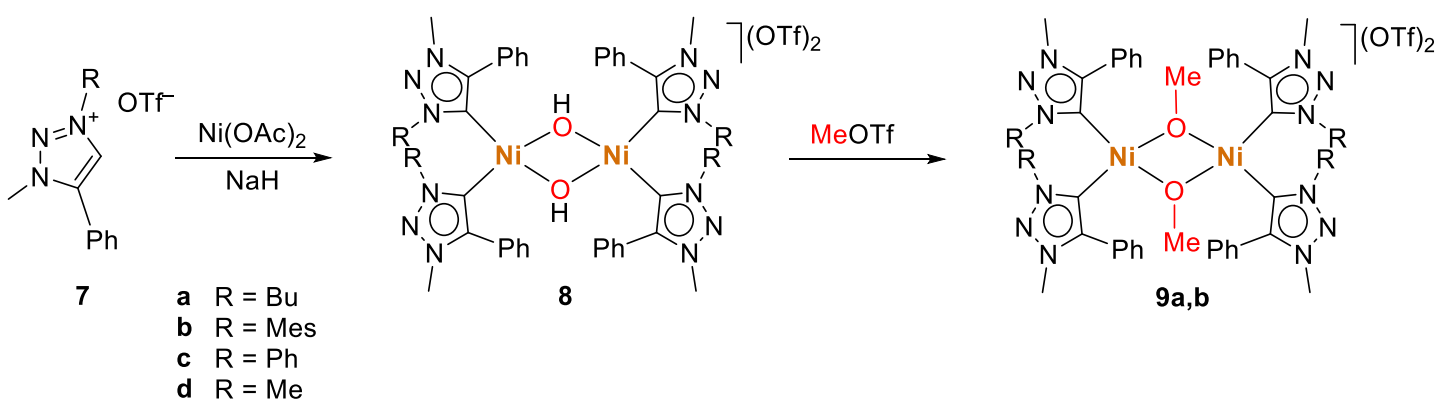

Scheme 3. Synthesis of triazolylidene dimetallic nicke(II) complexes $\mathbf{8 a - d}$ and $\mathbf{9 a , b}$.

Single crystals suitable for X-ray diffraction analysis were grown for complexes $\mathbf{8 a}, \mathbf{8 b}$, and $\mathbf{8 d}$ (Fig. 4). The global structures are fully consistent with the dimetallic arrangement, though the crystals of $\mathbf{8 d}$ and especially $\mathbf{8 b}$ showed substantial disorder in the aromatic substituents (Fig. S20), which prevents a detailed discussion of bond lengths and angles. It is worth noting that the $\mathrm{R}$ groups on the triazolylidene ligands are mutually anti for all the nickel complexes, thus minimising the steric repulsion. The mutual orientation of the nickel planes of complex 8a defined by the dihedral angle $\theta$ as well as the intermetallic Ni...Ni distance are comparable to the imidazolylidene analogues $\mathbf{2 a}-\mathbf{c}$, with values of $141^{\circ}$ and 2.87 respectively $\AA$. The geometry around the nickel center is less symmetric with $\mathrm{Ni}-\mathrm{O}$ bonds varying by $0.10 \AA$ and the $\mathrm{Ni}-\mathrm{C}$ bonds by $0.06 \AA$. Other metrics are very similar to complexes $\mathbf{2 a - c}$, suggesting that different NHC ligands only marginally affect the solid state structure of the dimetallic core. 


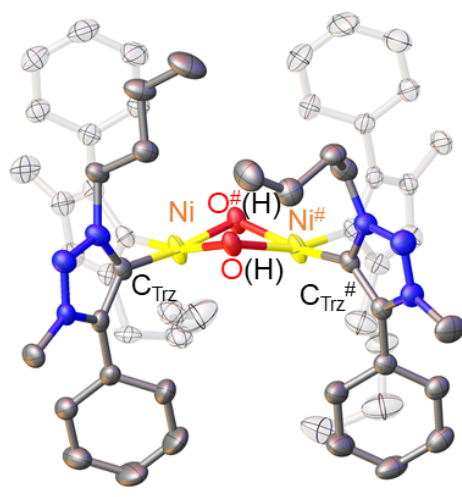

$8 \mathbf{a}$

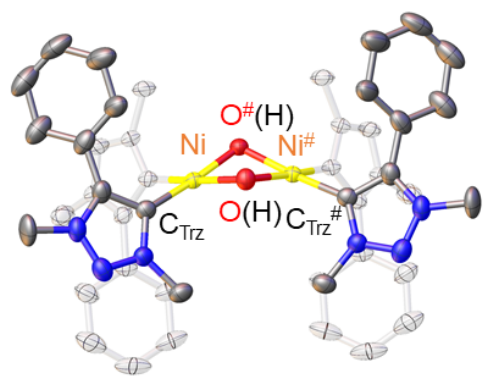

8d

Figure 4. ORTEP diagram of Ni complexes 8a and 8d (50\% probability level thermal ellipsoids; hydrogen atoms, non-coordinating OTf anions, as well as co-crystallized $\mathrm{CH}_{3} \mathrm{CN}$ molecules and the disorder of the phenyl groups of $\mathbf{8 d}$ omitted for clarity). Symmetry related atoms are marked with \# (1$\mathrm{x}, 1-\mathrm{y},-\mathrm{z}$ for $\mathbf{8 a},+\mathrm{x},-3 / 2-\mathrm{y},+\mathrm{z}$ for $\mathbf{8 d})$. Selected bond lengths and angles of complex 8a: $\mathrm{Ni} \ldots \mathrm{Ni}=$ 2.8709(5) $\AA, \mathrm{Ni}-\mathrm{O}=1.881(3)-1.977(4) \AA, \mathrm{Ni}-\mathrm{C}_{\mathrm{Trz}}=1.875(2)-1.929(2) \AA, \mathrm{C}_{\mathrm{Trz}}-\mathrm{Ni}-\mathrm{C}_{\mathrm{Trz}}=92(1)^{\circ}, \mathrm{O}-$ $\mathrm{Ni}-\mathrm{O}=83(2)^{\circ}, \mathrm{Ni}-\mathrm{O}-\mathrm{Ni}=97(1)^{\circ}, \theta=140.69^{\circ}$ (dihedral angle $\theta$ of the two Ni coordination planes defined as the average plane defined by $\mathrm{Ni}$, the two oxygen and the two carbon nuclei for each metal center).

The nucleophilicity of the bridging hydroxy groups was considerably altered upon introducing trz ligands. Specifically, exposure of complexes 8a-d to aliphatic alcohols did not induce any detectable reaction even when $\mathrm{MeOH}$ or $\mathrm{EtOH}$ was used as solvent and reactions extended up to $8 \mathrm{~h}$ (hexamethylbenzene as internal standard, Fig. S24). This inertness suggests a decreased nucleophilicity of the oxygens of the hydroxy groups and indicates that the NMR chemical shift of the bridging $\mathrm{OH}$ group is not a reliable proxy for the reactivity of these dinickel complexes since the higher field resonating and therefore more nucleophilic $\mathrm{OH}$ in complexes $\mathbf{8 a}-\mathbf{d}$ is more resistant to mild $\mathrm{ROH}$ acids than the lower field resonating $\mathrm{OH}$ in complexes $\mathbf{2 a}-\mathbf{c}$. Instead, the higher trans influence of triazolyidenes $v s$ imidazolylidenes may induce the NMR shift difference. In order to probe a possible steric hindrance imparted by the triazolylidene substituents might hamper the accessibility of the dimetallic core and prevent exchange reactions, the steric effects were quantified through calculation of the buried volume $\left(\mathrm{V}_{\text {Bur }}\right)$. $^{33}$ These calculations suggest, however, only a slightly larger shielding of the nickel center by the trz ligands in complexes $\mathbf{8 a}-\mathbf{d}\left(27.9-30.8 \% \mathrm{~V}_{\text {Bur }}\right)$ than by the imi ligands in complexes $\mathbf{2 a - c}$ (24.9-26.2\% $\mathrm{V}_{\mathrm{Bur}}$ ) and point to other factors than steric effects playing a more dominant role for governing the reactivity of these complexes. 
The accessibility of the $\mu-\mathrm{OH}$ unit was probed by reaction of complexes $\mathbf{8 a}, \mathbf{b}$ with MeOTf, which resulted in the clean formation of the methoxy-bridged complexes 9a,b (Scheme 3). Again, MeI was unreactive. Only a remarkably small upfield shift of the carbenic carbon resonance was observed in the ${ }^{13} \mathrm{C}$ NMR spectra of the complexes upon exchange of the bridging hydroxides for methoxides ( $\Delta \delta_{\mathrm{C}} \sim 2 \mathrm{ppm}, c f>10 \mathrm{ppm}$ for imidazolylidene analogues), suggesting only subtle variation in the electronic environment of the triazolylidene ligand upon modification of the bridging ligand. Attempts to crystallize complexes $\mathbf{9 a , b}$ have failed so far. Nonetheless, the formation of these complexes demonstrates that the oxygen donors of the dimeric core are easily accessible also with triazolylidene spectator ligands. Hence, the inertness of the triazolylidene complexes towards $\mathrm{MeOH}$ and EtOH is attributed to a decreased nucleophilicity of the bridging hydroxy groups of the $\left[(\operatorname{trz})_{2} \mathrm{Ni}(\mu-\mathrm{OH})_{2} \mathrm{Ni}(\operatorname{trz})_{2}\right]$ species when compared to $\left[(\mathrm{im})_{2} \mathrm{Ni}(\mu-\mathrm{OH})_{2} \mathrm{Ni}(\mathrm{im})_{2}\right]$, despite the higher field ${ }^{1} \mathrm{H}$ NMR resonances.

The decreased nucleophilicity of the $\mu-\mathrm{OH}$ unit was also evident from the stability of complexes 8a-d towards mild acids, including phenol $\left(p K_{\mathrm{a}}=10\right), \mathrm{NH}_{4} \mathrm{BF}_{4}\left(p K_{\mathrm{a}}=9.2\right)$ and even carbonic acid $\left(p K_{\mathrm{a}}=6.3\right)$. Likewise, no reaction occurred between complex 8a and $\mathrm{CO}_{2}$, thus contrasting the instability of the dimetallic core with imidazolylidene spectator ligands. Only in the presence of moderately strong acids, complex 8a transforms quantitatively into monomeric bis(carbene) nickel species (Fig. 5). For example, exposure to HOAc ( $\left.p K_{\mathrm{a}}=4.75\right)$ gave complex 12, which was characterized by HR-MS with a signal at $\mathrm{m} / \mathrm{z}=547.2304$ for $[\mathbf{1 2}$ $\mathrm{OTf}^{+}$, and NMR spectroscopy, which supported chelation by the characteristic ${ }^{13} \mathrm{C}$ NMR resonances at 171 and $20 \mathrm{ppm}$ and the presence of only one acetate ligand based on the corresponding integral ratio in the ${ }^{1} \mathrm{H}$ NMR spectrum. 


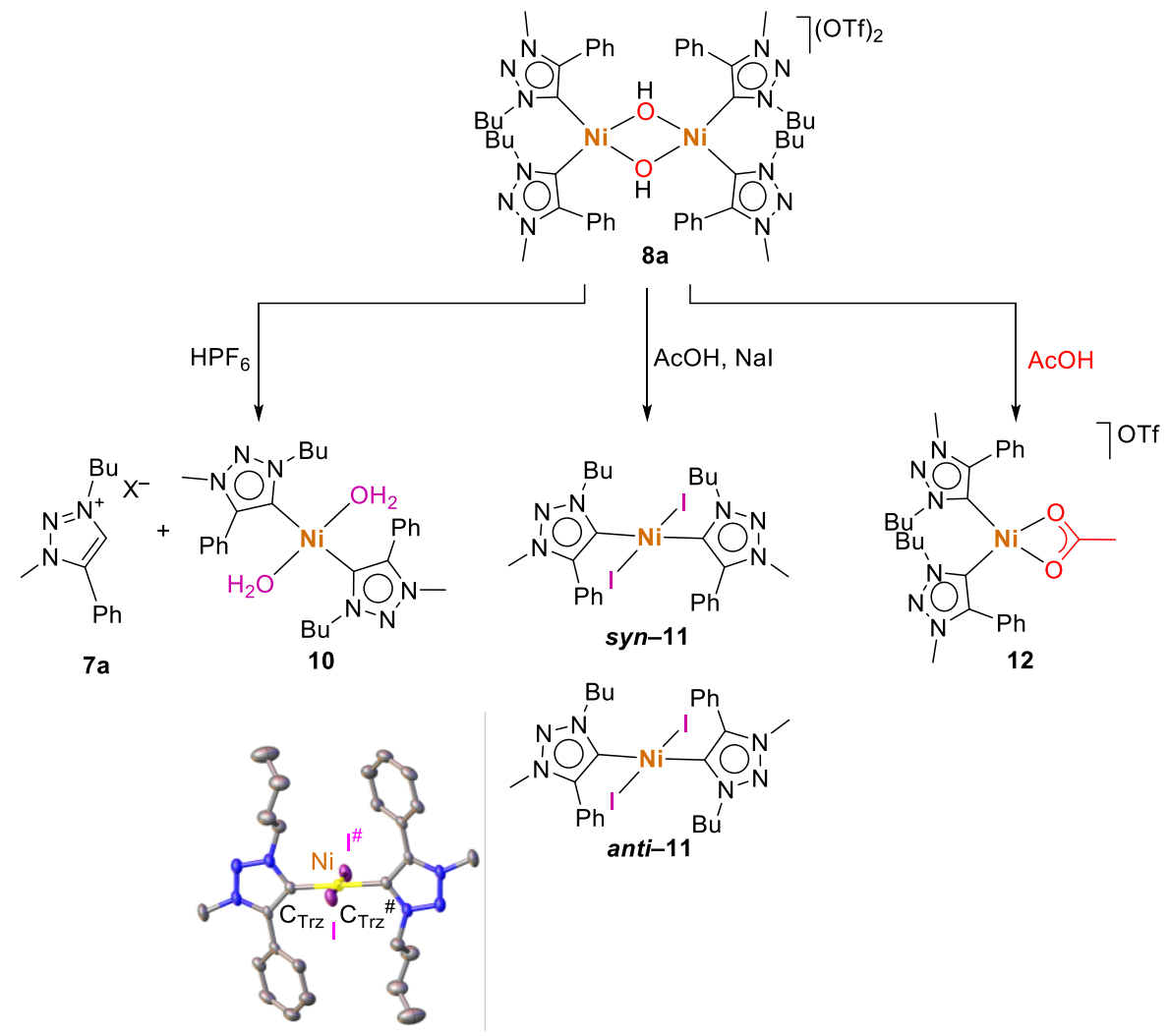

Figure 5. Reactivity studies with complex 8a and ORTEP diagram of Ni complex anti-11 (thermal ellipsoids are given at the $50 \%$ probability level; hydrogen atoms omitted for clarity).

Similarly, complex 8a reacts with formic acid in the presence of NaI through cleavage of the dimetallic structure and produces quantitatively complex $\mathbf{1 1}$ as a mixture of syn and anti isomers in 3:1 ratio according to the two distinct sets of resonances for the triazolylidene nuclei observed by ${ }^{1} \mathrm{H}$ and ${ }^{13} \mathrm{C}$ NMR analysis. In agreement with the syn/anti notion, HR-MS analysis showed the presence of only one molecular ion peak at $\mathrm{m} / \mathrm{z}=615.1236$, assigned to the $\left[\mathrm{Ni}(\operatorname{Trz})_{2}(\mathrm{I})\right]^{+}$cation. A syn/anti rather than a cis/trans isomeric relationship has been deduced from the similar ${ }^{13} \mathrm{C}$ NMR resonance frequencies for the carbenic nucleus of both isomers $\left(\delta_{\mathrm{C}-}\right.$ $\mathrm{Ni}=144.4$ and $144.3 \mathrm{ppm}$, respectively). In related palladium complexes $\left[\mathrm{Pd}(\mathrm{NHC})_{2} \mathrm{Cl}_{2}\right]$, the carbene carbon resonance differs by a diagnostic $30 \mathrm{ppm}$ between the cis and the trans isomer. ${ }^{34-37}$ The absence of a significant shift difference between the carbenic carbon resonance as well as the absence of any isomeric mixture when using symmetric imi ligands ( $c f$ complex 5) therefore suggests the trans configuration with syn and anti isomers. The trans configuration is supported by the crystallographic analysis of complex $\mathbf{5}$ and the absence of any NOE between the trz substituents, implying a distance of more than $3 \AA$ between the two ligands. Final structural confirmation was obtained by X-ray diffraction analysis of crystals grown from an isomeric mixture, which revealed anti-11 in a trans configuration (Fig. 5). 
Addition of $\mathrm{HPF}_{6}$ as a stronger acid $\left(\mathrm{p} K_{\mathrm{a}}<1\right)$ to $\mathbf{8 a}$ instantaneously afforded a mixture of the monometallic aqua complex $\left[\mathrm{Ni}(\operatorname{trz})_{2}\left(\mathrm{OH}_{2}\right)_{2}\right]\left(\mathrm{PF}_{6}\right)_{2} \mathbf{1 0}$ and the triazolium salt $\mathbf{7 a}$ in about 1:1 ratio according to ${ }^{1} \mathrm{H}$ NMR analysis (Fig. 5). The new Ni complex $\mathbf{1 0}$ did not show any characteristic high-field resonance for the bridging $\mathrm{OH}$ unit and instead featured a resonance at $2.14 \mathrm{ppm}$, which was attributed to coordinated $\mathrm{H}_{2} \mathrm{O}$ based on the similarity to the values reported for a related monometallic bis(aquo) Ni(II) complex containing imi ligands (2.05 ppm). ${ }^{38}$ Formation of the aqua complex $\mathbf{1 0}$ was also supported by the molecular ion peak observed by HR-MS at $\mathrm{m} / \mathrm{z}=669.2042$, which is in agreement with $\left[\mathbf{1 0}-\mathrm{PF}_{6}\right]^{+}$(calcd 669.2046). In addition, the geminal $\mathrm{NCH}_{2}$ protons of the butyl groups are diastereotopic, suggesting restricted rotation about the $\mathrm{Ni}-\mathrm{C}_{\text {Carb }}$ bond. Attempts to crystallize this complex failed, in parts because of the instability of complex $\mathbf{1 0}$ as identified by the gradual formation of the corresponding triazolium salt according to ${ }^{1} \mathrm{H}$ NMR monitoring (85\% decomposition after 3 days).

Like the imidazolylidene analogues, complexes 8a-d do not react with bases and no change was observed in the presence of $\mathrm{NaOMe}, \mathrm{NaCO}_{3}$, or $\mathrm{Et}_{3} \mathrm{~N}$. These dinuclear species are thus remarkably stable towards nucleophiles, indicating a low (Lewis) acidity of both the $\mu$ hydroxid protons and the nickel(II) centers.

In contrast, the dinuclear complexes exhibit exclusively nucleophilic behavior at the bridging oxygen site, which is more pronounced with imi spectator ligands than with trz. This reactivity leads to $\mathrm{H}^{+} v s \mathrm{H}_{3} \mathrm{C}^{+}$exchange in the presence of MeOTf, and to formation of the aqua ligand in the presence of a proton source (Scheme 4). Such protonation induces cleavage of the dimeric core, as supported by the formation of complex 10. This aqua species is unstable, and forms either a neutral complex in the presence of coordinating anions or decomposes upon protonation of the second Lewis basic site, via the carbene to form the azolium salt (Scheme 4). Such protonation may also take place as the first step in the exchange of the bridging $\mathrm{OH}$ group for an alkoxide OR. According to this model, the lower nucleophilicity of the bridging oxygen in the trz complexes $\mathbf{8}$ compared to that of the imi system $\mathbf{2}$ therefore rationalizes the enhanced stability of the $\left[(\operatorname{trz})_{2} \mathrm{Ni}(\mu-\mathrm{OH})_{2} \mathrm{Ni}(\operatorname{trz})_{2}\right]^{2+}$ complexes towards $\mathrm{ROH}$ and mild acids $\left(\mathrm{p} K_{\mathrm{a}}>6\right)$. 


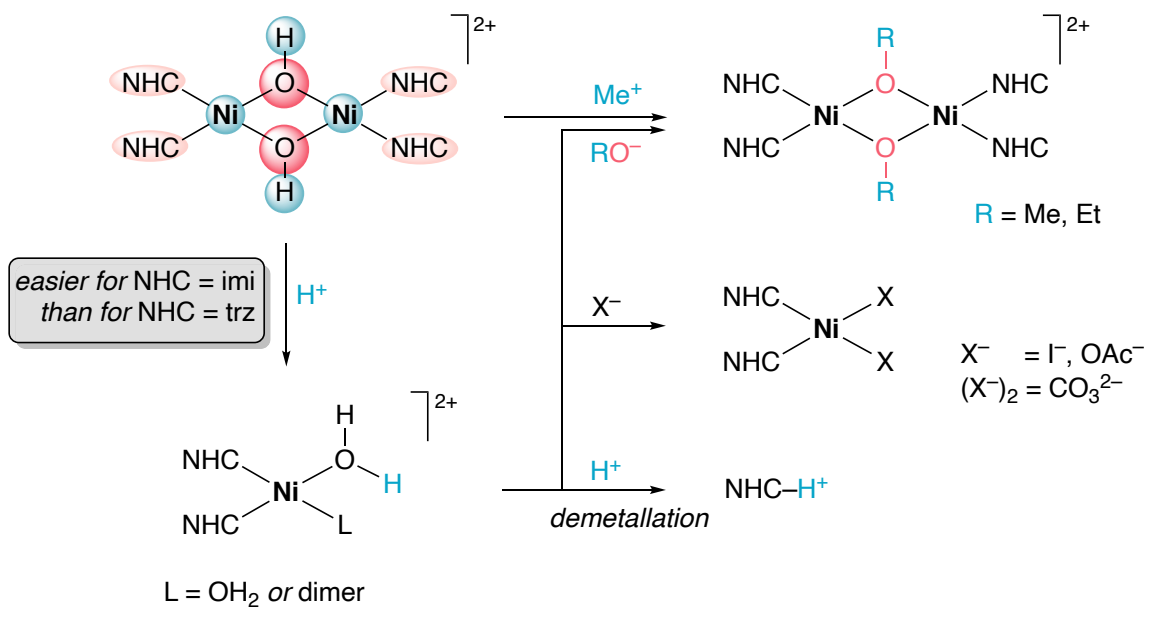

Scheme 4. Summary of the reactivity of dinuclear $\mathrm{Ni}_{2}$ complexes stabilized by $\mathrm{NHC}$ ligands $(\mathrm{NHC}=$ imi, trz). In the parent complex potentially Lewis acidic sites are highlighted in blue, Lewis basic sites in red, with hydroxide oxygens as most basic sites shown in darker red.

\section{Conclusions}

Novel cationic dimetallic nickel(II) bis( $\mu-\mathrm{OH})$ complexes supported by triazolylidene and imidazolylidene ligands were synthesized starting from cheap and abundant nickel acetate. Surprisingly, the complexes are inert towards strong nucleophiles and bases, indicating low Lewis and Brønsted acidity of the nickel centers and the protons of the $\mu-\mathrm{OH}$ ligand. A series of stoichiometric experiments with electrophiles disclosed a preferential reactivity at the oxygen nuclei of the bridging $\mu-\mathrm{OH}$ ligands, with the outcome of the reaction depending on the nature of the coordinating NHC ligand and on the electrophile. Specifically, selective oxygen alkylation takes place with MeOTf, leading to dimetallic complexes with alkoxid bridging ligands. Acids cleave the dinuclear core through protonation of the $\mu-\mathrm{OH}$ units initially, and subsequently also the carbenic site to yield the corresponding azolium salts. Carbene protonation is successfully prevented when providing a coordinating anion. Imidazolylidene ligated complexes feature more nucleophilic $\mu-\mathrm{OH}$ sites than triazolylidene analogues and react even with mild acids $\left(6<\mathrm{p} K_{\mathrm{a}}<10\right)$ to give monomeric species, whereas stronger acids $\left(\mathrm{p} K_{\mathrm{a}}<5\right)$ are required to break the dinuclear core of the triazolylidene analogues. This different behavior and specifically the enhanced stability of the dimetallic $\mathrm{Ni}(\mu-\mathrm{OH})_{2} \mathrm{Ni}$ core when supported by triazolylidene ligands holds promises for catalytic applications that require a dimetallic active site. 


\section{Experimental}

Ligands 1,3-dimethyl-imidazolium iodide $\operatorname{salt}^{39}$ (1a), 1b 1,3-diisopropyl-imidazolium hexafluorophosphate salt ${ }^{40}$ (1b), 1,3-diisobutyl-imidazolium hexafluorophosphate salt ${ }^{41}$ (1c), 1-butyl-3-methyl-4-phenyl-1,2,3-triazolium triflate salt ${ }^{42}$ (7a), 1-mesityl-3-methyl-4-phenyl1,2,3-triazolium triflate salt ${ }^{43}$ (7b), 1,4-diphenyl-3-methyl-1,2,3-triazolium triflate salt ${ }^{42}$ (7c) and 1-3-dimethyl-4-phenyl-1,2,3-triazolium triflate salt ${ }^{43}$ (7d) were synthesized following procedures already reported in the literature. Analyses of complex $\mathbf{5}$ were consistent with the values previously reported for the same compound. ${ }^{31}$ All other reagents were commercially available and used as received. Unless specified otherwise, NMR spectra were recorded at $25^{\circ} \mathrm{C}$ with Bruker spectrometers operating at 300 or $400 \mathrm{MHz}\left({ }^{1} \mathrm{H} \mathrm{NMR}\right)$, and $100 \mathrm{MHz}\left({ }^{13} \mathrm{C}\right.$ NMR), respectively. Chemical shifts ( $\delta$ in ppm, coupling constants $J$ in $\mathrm{Hz}$ ) were referenced to residual solvent signals $\left({ }^{1} \mathrm{H},{ }^{13} \mathrm{C}\right)$. Assignments are based on homo- and heteronuclear shift correlation spectroscopy. The purity of bulk samples of the complexes has been established by NMR spectroscopy, and by elemental analysis, which were performed at the University of Bern Microanalytic Laboratory by using a Thermo Scientific Flash 2000 CHNS-O elemental analyzer. High-resolution mass spectrometry was carried out with a Thermo Scientific LTQ Orbitrap XL (ESI-TOF).

\section{General procedure for the synthesis of the nickel complexes}

Triazolium/Imidazolium salts and $\mathrm{NaH}$ were dissolved in dry THF $(10 \mathrm{~mL})$ under an inert atmosphere and stirred for $30 \mathrm{~min}$ at $0{ }^{\circ} \mathrm{C}$. The mixture was cannulated into a suspension of nickel acetate in THF $(5 \mathrm{~mL})$. The reaction mixture was stirred for $8 \mathrm{~h}$ at room temperature. All volatiles were then removed in vacuo. $\mathrm{CH}_{2} \mathrm{Cl}_{2}(30 \mathrm{~mL})$ was added to the solid and the suspension was filtrated through a short pad of Celite. Evaporation of all solvent afforded a solid, which was purified by precipitation $\left(\mathrm{Et}_{2} \mathrm{O}\right)$ to obtain the desired complex in high purity.

\section{Synthesis of 2a}

The reaction of imidazolium salt 1a $(200 \mathrm{mg}, 0.89 \mathrm{mmol}), \mathrm{Ni}(\mathrm{OAc})_{2}\left(\mathrm{H}_{2} \mathrm{O}\right)_{4}(112 \mathrm{mg}, 0.45$ $\mathrm{mmol})$, and $\mathrm{NaH}(60 \mathrm{mg}, 2.7 \mathrm{mmol})$ in THF (10 mL) according to the general procedure yielded complex $2 \mathbf{a}$ as a yellow crystalline powder ( $81 \mathrm{mg}, 46 \%$ ).

${ }^{1} \mathrm{H}$ NMR (400 MHz, CD 3 CN): $\delta 6.96\left(\mathrm{~s}, 4 \mathrm{H}, \mathrm{H}_{\mathrm{Im}}\right), 4.14\left(\mathrm{~s}, 12 \mathrm{H}, \mathrm{N}-\mathrm{CH}_{3}\right),-2.63(\mathrm{~s}, 1 \mathrm{H}, \mathrm{OH})$. ${ }^{13} \mathrm{C}\left\{{ }^{1} \mathrm{H}\right\}$ NMR (101 MHz, $\left.\mathrm{CD}_{3} \mathrm{CN}\right): \delta 158.38(\mathrm{C}-\mathrm{Ni}), 124.71\left(\mathrm{C}_{\mathrm{Im}} \mathrm{H}\right), 38.32\left(\mathrm{~N}-\mathrm{CH}_{3}\right) . \mathrm{HR}-\mathrm{MS}$ (ESI): calcd for $\mathrm{C}_{20} \mathrm{H}_{34} \mathrm{IN}_{8} \mathrm{Ni}_{2} \mathrm{O}_{2}[\mathrm{M}-\mathrm{I}]^{+} \mathrm{m} / \mathrm{z}=661.0551$ (found 661.0552). Anal. Calcd for $\mathrm{C}_{20} \mathrm{H}_{34} \mathrm{I}_{2} \mathrm{~N}_{8} \mathrm{Ni}_{2} \mathrm{O}_{2}$ (789.74): C, 30.42; H, 4.34; N, 14.19. Found: C, 30.32; H, 4.18; N, 14.48. 


\section{Synthesis of $2 \mathrm{a}\left(\mathrm{BPh}_{4}\right)$}

To a solution of $80 \mathrm{mg}$ of $\mathbf{2 a}(0.10 \mathrm{mmol})$ in $\mathrm{CH}_{3} \mathrm{CN}(3 \mathrm{~mL}), \mathrm{Na}\left(\mathrm{BPh}_{4}\right)(150 \mathrm{mg}, 0.44 \mathrm{mmol})$ was added and the reaction mixture stirred at room temperature for $30 \mathrm{~min}$. The solvent was removed and the solid extracted with $\mathrm{CH}_{2} \mathrm{Cl}_{2}$ and washed with $\mathrm{H}_{2} \mathrm{O}(3 \times 10 \mathrm{~mL})$ to give $\mathbf{2 a}\left(\mathbf{B P h}_{4}\right)(106 \mathrm{mg}, 90 \%)$.

${ }^{1} \mathrm{H}$ NMR (400 MHz, $\left.\mathrm{CD}_{3} \mathrm{CN}\right): \delta 7.31-7.27\left(\mathrm{~m}, 16 \mathrm{H}, \mathrm{H}_{\mathrm{Ph}}\right), 7.01\left(\mathrm{t}, \mathrm{J}=8 \mathrm{~Hz}, 16 \mathrm{H}, \mathrm{H}_{\mathrm{Ph}}\right), 6.93(\mathrm{~s}$, $\left.8 \mathrm{H}, \mathrm{H}_{\mathrm{Im}}\right), 6.86(\mathrm{t}, 8 \mathrm{H}, \mathrm{J}=8 \mathrm{~Hz}), 4.11\left(\mathrm{~s}, 12 \mathrm{H}, \mathrm{N}-\mathrm{CH}_{3}\right),-2.61(\mathrm{~s}, 2 \mathrm{H}, \mathrm{OH}) .{ }^{13} \mathrm{C}\left\{{ }^{1} \mathrm{H}\right\} \mathrm{NMR}(101$ $\left.\mathrm{MHz}, \mathrm{CD}_{3} \mathrm{CN}\right): \delta 158.17(\mathrm{C}-\mathrm{Ni}), 136.67\left(\mathrm{C}_{\mathrm{Ph}}\right), 126.54\left(\mathrm{C}_{\mathrm{Ph}}, \mathrm{q}, \mathrm{J}_{\mathrm{C}-\mathrm{B}}=49 \mathrm{~Hz}\right), 124.95\left(\mathrm{C}_{\mathrm{Im}} \mathrm{H}\right)$, $124.75\left(\mathrm{C}_{\mathrm{Ph}}\right), 122.70\left(\mathrm{C}_{\mathrm{Ph}}\right), 38.10\left(\mathrm{NCH}_{3}\right)$. HR-MS (ESI): calcd for $\mathrm{C}_{44} \mathrm{H}_{54} \mathrm{BN}_{8} \mathrm{Ni}_{2} \mathrm{O}_{2}[\mathrm{M}-$ $\left.\mathrm{BPh}_{4}\right]^{+} \mathrm{m} / \mathrm{z}=853.3164$ (found 853.3159). Anal. Calcd for $\mathrm{C}_{68} \mathrm{H}_{74} \mathrm{~B}_{2} \mathrm{~N}_{8} \mathrm{Ni}_{2} \mathrm{O}_{2}$ (1174.40): $\mathrm{C}$, 69.55; H, 6.35; N, 9.54. Found: C, 69.71; H, 6.28; N, 9.62.

\section{Synthesis of $2 b$}

The reaction of imidazolium salt $\mathbf{1 b}(200 \mathrm{mg}, 1.01 \mathrm{mmol}), \mathrm{Ni}(\mathrm{OAc})_{2}\left(\mathrm{H}_{2} \mathrm{O}\right)_{4}(137 \mathrm{mg}, 0.55$ $\mathrm{mmol})$, and $\mathrm{NaH}(78 \mathrm{mg}, 3.1 \mathrm{mmol})$ in THF $(10 \mathrm{~mL})$ according to the general procedure yielded complex $\mathbf{2 b}$ as a yellow crystalline powder (93 $\mathrm{mg}, 32 \%)$.

${ }^{1} \mathrm{H}$ NMR (400 MHz, $\left.\mathrm{CD}_{3} \mathrm{CN}\right): \delta 7.16$ (s, 4H, HIm), 6.35-6.28 (m, 4H, N-CH), 1.57 (d, J = 6 $\left.\mathrm{Hz}, 6 \mathrm{H}, \mathrm{CH}_{3}\right), 1.34\left(\mathrm{~d}, \mathrm{~J}=6 \mathrm{~Hz}, 6 \mathrm{H}, \mathrm{CH}_{3}\right),-3.16(\mathrm{~s}, 1 \mathrm{H}, \mathrm{OH}) .{ }^{13} \mathrm{C}\left\{{ }^{1} \mathrm{H}\right\} \mathrm{NMR}(101 \mathrm{MHz}$, $\left.\mathrm{CD}_{3} \mathrm{CN}\right): \delta 153.81(\mathrm{C}-\mathrm{Ni}), 120.37\left(\mathrm{C}_{\mathrm{Im}} \mathrm{H}\right), 53.88\left(\mathrm{~N}-\mathrm{CH}_{2}\right), 24.37\left(\mathrm{CH}_{3}\right), 22.73\left(\mathrm{CH}_{3}\right)$

HR-MS (ESI): calcd for $\mathrm{C}_{36} \mathrm{H}_{66} \mathrm{~F}_{6} \mathrm{~N}_{8} \mathrm{Ni}_{2} \mathrm{O}_{2} \mathrm{P}\left[\mathrm{M}-\mathrm{PF}_{6}\right]^{+} \mathrm{m} / \mathrm{z}=903.3657$ (found 903.3652). Anal. Calcd for $\mathrm{C}_{36} \mathrm{H}_{66} \mathrm{~F}_{12} \mathrm{~N}_{8} \mathrm{NiO}_{2} \mathrm{P}_{2}$ (1150.29): C, 41.17; H, 6.33; N, 10.67. Found: C, 41.30; H, 6.42; $\mathrm{N}, 10.85$.

\section{Synthesis of 2c}

The reaction of imidazolium salt 1 c $(300 \mathrm{mg}, 0.92 \mathrm{mmol}), \mathrm{Ni}(\mathrm{OAc})_{2}\left(\mathrm{H}_{2} \mathrm{O}\right)_{4}(120 \mathrm{mg}, 0.48$ $\mathrm{mmol})$, and $\mathrm{NaH}(72 \mathrm{mg}, 3.0 \mathrm{mmol})$ in THF $(10 \mathrm{~mL})$ according to the general procedure yielded complex $2 \mathbf{c}$ as a yellow crystalline powder (101 mg, 38\%).

${ }^{1} \mathrm{H}$ NMR (400 MHz, $\mathrm{CD}_{3} \mathrm{CN}$ ): $\delta 7.00$ (s, 4H, $\mathrm{H}_{\mathrm{Im}}$ ), 4.85-4.79 (m, 4H, N-CH $\mathrm{CH}_{2}$ ), 4.20-4.16 (m, $\left.4 \mathrm{H}, \mathrm{N}-\mathrm{CH}_{2}-\right), 2.48-2.41\left(\mathrm{~m}, 4 \mathrm{H},-\mathrm{CH}-\left(\mathrm{CH}_{3}\right)_{2}\right), 1.06\left(\mathrm{~d}, \mathrm{~J}=6 \mathrm{~Hz}, 6 \mathrm{H}, \mathrm{CH}_{3}\right), 0.93(\mathrm{~d}, \mathrm{~J}=6 \mathrm{~Hz}$, $\left.6 \mathrm{H}, \mathrm{CH}_{3}\right),-3.92(\mathrm{~s}, 1 \mathrm{H}, \mathrm{OH}) .{ }^{13} \mathrm{C}\left\{{ }^{1} \mathrm{H}\right\}$ NMR $\left(101 \mathrm{MHz}, \mathrm{CD}_{3} \mathrm{CN}\right): \delta 155.49(\mathrm{C}-\mathrm{Ni}), 123.92$ $\left(\mathrm{C}_{\mathrm{Im}} \mathrm{H}\right), 58.44\left(\mathrm{~N}-\mathrm{CH}_{2}\right), 30.10\left(\mathrm{CH}-\left(\mathrm{CH}_{3}\right)_{2}\right), 20.66\left(\mathrm{CH}_{3}\right), 20.27\left(\mathrm{CH}_{3}\right)$ HR-MS (ESI): calcd for $\mathrm{C}_{44} \mathrm{H}_{82} \mathrm{~N}_{8} \mathrm{NiO}_{2}[\mathrm{M}]^{++} \mathrm{m} / \mathrm{z}=435.2628$ (found 435.2625). Anal. Calcd for $\mathrm{C}_{44} \mathrm{H}_{82} \mathrm{~F}_{12} \mathrm{~N}_{8} \mathrm{NiO}_{2} \mathrm{P}_{2}$ (1162.50): C, 45.46; H, 7.11; N, 9.64. Found: C, 45.38; H, 6.98; N, 9.55.

\section{Synthesis of 3a}


Method A: Complex 2a (20 mg, $25 \mu \mathrm{mol})$ was dissolved in $\mathrm{CD}_{3} \mathrm{CN}(0.4 \mathrm{~mL})$ and $\mathrm{MeOH}(4 \mu \mathrm{L}$, $100 \mu \mathrm{mol})$ was added. Quantitative conversion to complex 3a $(\mathrm{X}=\mathrm{I})$ was observed within 5 min according to monitoring by NMR. Crystals of the product were grown by slow diffusion of $\mathrm{Et}_{2} \mathrm{O}$ into a $\mathrm{MeOH}(2 \mathrm{~mL})$ solution of complex 2a (100 mg, $\left.0.13 \mathrm{mmol}\right)$. All attempts to dry the crystals in vacuo resulted in the formation of complex $\mathbf{2 a}$.

Method B: A solution of complex 2a $(160 \mathrm{mg}, 0.20 \mathrm{mmol})$ in $\mathrm{CH}_{3} \mathrm{CN}(5 \mathrm{~mL})$ was treated with $\operatorname{MeOTf}(0.64 \mathrm{~mL}, 0.56 \mathrm{mmol})$ and stirred for $1 \mathrm{~min}$. The solvent was evaporated, and the solid was dissolved in a minimum amount of $\mathrm{CH}_{2} \mathrm{Cl}_{2}$ and precipitated with $\mathrm{Et}_{2} \mathrm{O}$ to yield complex 3a $(\mathrm{X}=\mathrm{OTf})$ as an analytically pure solid (150 $\mathrm{mg}, 90 \%)$.

${ }^{1} \mathrm{H}$ NMR (400 MHz, $\left.\mathrm{CD}_{3} \mathrm{CN}\right): \delta 6.96\left(\mathrm{~s}, 4 \mathrm{H}, \mathrm{H}_{\mathrm{Im}}\right), 4.18\left(\mathrm{~s}, 12 \mathrm{H}, \mathrm{CH}_{3}\right), 3.28\left(\mathrm{~m}, 3 \mathrm{H}, \mathrm{CH}_{3}-\mathrm{O}\right)$. ${ }^{13} \mathrm{C}\left\{{ }^{1} \mathrm{H}\right\}$ NMR $\left(101 \mathrm{MHz}, \mathrm{CD}_{3} \mathrm{CN}\right): \delta 146.04(\mathrm{C}-\mathrm{Ni}), 124.96\left(\mathrm{C}_{\mathrm{Im}} \mathrm{H}\right), 60.87\left(\mathrm{CH}_{3} \mathrm{O}\right), 38.24$ $\left(\mathrm{NCH}_{3}\right.$ ). HR-MS (ESI): calcd for $\mathrm{C}_{22} \mathrm{H}_{38} \mathrm{IN}_{8} \mathrm{Ni}_{2} \mathrm{O}_{2}[\mathrm{M}-\mathrm{I}]^{+} \mathrm{m} / \mathrm{z}=689.0863$ (found 689.0861). Anal. Calcd for $\mathrm{C}_{24} \mathrm{H}_{38} \mathrm{~F}_{6} \mathrm{~N}_{8} \mathrm{Ni}_{2} \mathrm{O}_{8} \mathrm{~S}_{2}$ (862.11): C, 33.44; H, 4.44; N, 13.22. Found: C, 33.28; H, $4.32 ; \mathrm{N}, 13.40$.

\section{Synthesis of $3 b$}

Method A: Complex $2 \mathbf{b}(20 \mathrm{mg}, 19 \mu \mathrm{mol})$ was dissolved in $\mathrm{CD}_{3} \mathrm{CN}(0.4 \mathrm{~mL})$ and $\mathrm{MeOH}(4 \mu \mathrm{L}$, $100 \mu \mathrm{mol})$ was added. Quantitative conversion to complex $\mathbf{3 b}\left(\mathrm{X}=\mathrm{PF}_{6}\right)$ was observed within 5 min by NMR spectroscopic monitoring. Crystals of the product were grown by slow diffusion of $\mathrm{Et}_{2} \mathrm{O}$ into a $\mathrm{MeOH}(2 \mathrm{~mL})$ solution of complex $\mathbf{2 b}(100 \mathrm{mg}, 94 \mu \mathrm{mol})$. All attempts to dry the crystals resulted in formation of complex $\mathbf{2} \mathbf{b}$.

Method B: The triflate salt of complex $\mathbf{3 b}$ was obtained by adding MeOTf ( $64 \mu \mathrm{L}, 56 \mu \mathrm{mol})$ to complex $2 \mathbf{b}(160 \mathrm{mg}, 15 \mu \mathrm{mol})$ in $\mathrm{CH}_{3} \mathrm{CN}(5 \mathrm{~mL})$. After $1 \mathrm{~min}$, the solvent was evaporated, and the solid was dissolved in a minimum amount of $\mathrm{CH}_{2} \mathrm{Cl}_{2}$ and precipitated with $\mathrm{Et}_{2} \mathrm{O}$ to afford the title product $\mathbf{3 b}(\mathrm{X}=$ OTf; $14 \mathrm{mg}, 88 \%)$.

${ }^{1} \mathrm{H}$ NMR $\left(400 \mathrm{MHz}, \mathrm{CD}_{3} \mathrm{CN}\right): \delta 7.39$ (s, 4H, HIm), 5.49-5.42 (m, 2H, N-CH), 3.23 (s, 3H, O$\left.\mathrm{CH}_{3}\right), 1.47\left(\mathrm{~d}, \mathrm{~J}=6 \mathrm{~Hz}, 6 \mathrm{H}, \mathrm{CH}_{3}\right), 1.18\left(\mathrm{~d}, \mathrm{~J}=6 \mathrm{~Hz}, 6 \mathrm{H}, \mathrm{CH}_{3}\right) .{ }^{13} \mathrm{C}\left\{{ }^{1} \mathrm{H}\right\} \mathrm{NMR}(101 \mathrm{MHz}$, $\left.\mathrm{CD}_{3} \mathrm{CN}\right)$ : $\delta 141.99(\mathrm{C}-\mathrm{Ni}), 122.23\left(\mathrm{C}_{\mathrm{Im}} \mathrm{H}\right), 60.35\left(\mathrm{O}-\mathrm{CH}_{3}\right), 54.18\left(\mathrm{~N}-\mathrm{CH}_{2}\right), 24.14\left(\mathrm{CH}_{3}\right), 22.27$ $\left(\mathrm{CH}_{3}\right)$. HR-MS (ESI): calcd for $\mathrm{C}_{38} \mathrm{H}_{70} \mathrm{~F}_{6} \mathrm{~N}_{8} \mathrm{Ni}_{2} \mathrm{O}_{2} \mathrm{P}\left[\mathrm{M}-\mathrm{PF}_{6}\right]^{+} \mathrm{m} / \mathrm{z}=931.3965$ (found 931.3967). Anal. Calcd for $\mathrm{C}_{40} \mathrm{H}_{70} \mathrm{~F}_{6} \mathrm{~N}_{8} \mathrm{Ni}_{2} \mathrm{O}_{8} \mathrm{~S}_{2}$ (1086.54): C, 44.22; H, 6.49; N, 10.31. Found: C, 44.31; $\mathrm{H}, 6.42 ; \mathrm{N}, 10.38$.

\section{Synthesis of 3c}

Complex 2 c $(20 \mathrm{mg}, 17 \mu \mathrm{mol})$ was dissolved in $\mathrm{CD}_{3} \mathrm{CN}(0.4 \mathrm{~mL})$ and $\mathrm{MeOH}(4 \mu \mathrm{L}, 100 \mu \mathrm{mol})$ was added. After $8 \mathrm{~h}$, NMR spectroscopy revealed a 7:3 mixture of complex $\mathbf{3 c}\left(\mathrm{X}=\mathrm{PF}_{6}\right)$ and 2c. Crystals of the title complex were grown by slow diffusion of $\mathrm{Et}_{2} \mathrm{O}$ into a $\mathrm{MeOH}(2 \mathrm{~mL})$ 
solution of complex $2 \mathbf{c}(100 \mathrm{mg}, 85 \mu \mathrm{mol})$. Attempts to isolate and dry the crystals resulted in the formation of the starting material, complex $2 \mathbf{c}$.

Method B: A solution of complex $2 \mathrm{c}(160 \mathrm{mg}, 0.14 \mathrm{mmol})$ in $\mathrm{CH}_{3} \mathrm{CN}(5 \mathrm{~mL})$ was treated with MeOTf $(0.64 \mathrm{~mL}, 0.56 \mathrm{mmol})$. The reaction was stirred for $5 \mathrm{~min}$, and the solvent was evaporated. The residual solid was dissolved in a minimum amount of $\mathrm{CH}_{2} \mathrm{Cl}_{2}$ and precipitated with $\mathrm{Et}_{2} \mathrm{O}$ to afford complex $3 \mathbf{c}$ as an analytically pure solid (110 mg, 68\%).

${ }^{1} \mathrm{H}$ NMR (400 MHz, $\mathrm{CD}_{3} \mathrm{CN}$ ): $\delta 7.41$ (s, 4H, $\mathrm{H}_{\mathrm{Im}}$ ), 5.51-5.45 (m, 2H, N-CH $\left.\mathrm{CH}_{2}\right)$, 4.94-4.88 (m, $\left.4 \mathrm{H}, \mathrm{N}-\mathrm{CH}_{2}\right), 3.25\left(\mathrm{~s}, 3 \mathrm{H}, \mathrm{OCH}_{3}\right), 3.02-2.96\left(\mathrm{~m}, 4 \mathrm{H},-\mathrm{CH}-\left(\mathrm{CH}_{3}\right)_{2}\right), 1.51\left(\mathrm{~d}, \mathrm{~J}=6 \mathrm{~Hz}, 6 \mathrm{H}, \mathrm{CH}_{3}\right)$, $1.20\left(\mathrm{~d}, \mathrm{~J}=6 \mathrm{~Hz}, 6 \mathrm{H}, \mathrm{CH}_{3}\right) .{ }^{13} \mathrm{C}\left\{{ }^{1} \mathrm{H}\right\}$ NMR $\left(101 \mathrm{MHz}, \mathrm{CD}_{3} \mathrm{CN}\right): \delta 142.02(\mathrm{C}-\mathrm{Ni}), 122.16$ $\left(\mathrm{C}_{\mathrm{Im}} \mathrm{H}\right), 60.38\left(\mathrm{O}-\mathrm{CH}_{3}\right), 54.60\left(\mathrm{~N}-\mathrm{CH}_{2}\right), 29.05\left(\mathrm{CH}-\left(\mathrm{CH}_{3}\right)_{2}\right), 22.82\left(\mathrm{CH}_{3}\right), 22.46\left(\mathrm{CH}_{3}\right)$. HRMS (ESI): calcd for $\mathrm{C}_{46} \mathrm{H}_{86} \mathrm{~F}_{6} \mathrm{~N}_{8} \mathrm{Ni}_{2} \mathrm{O}_{2} \mathrm{P}\left[\mathrm{M}-\mathrm{PF}_{6}\right]^{+} \mathrm{m} / \mathrm{z}=1043.5217$ (found 1043.5221). Anal. Calcd for $\mathrm{C}_{48} \mathrm{H}_{86} \mathrm{~F}_{6} \mathrm{~N}_{8} \mathrm{Ni}_{2} \mathrm{O}_{8} \mathrm{~S}_{2}$ (1198.76): C, 48.09; H, 7.23; N, 9.35. Found: C, 48.22; H, 7.12; N, 9.42 .

\section{Synthesis of 4}

Complex 2a $(20 \mathrm{mg}, 25 \mu \mathrm{mol})$ was dissolved in $\mathrm{CD}_{3} \mathrm{CN}(0.3 \mathrm{~mL})$ in an NMR tube. To the solution, ethanol $(10 \mu \mathrm{L}, 250 \mu \mathrm{mol})$ was added and the reaction monitored by NMR over time, revealing full conversion to 4 after $10 \mathrm{~min}$ of reaction time. Crystals of the product were grown by diffusion of $\mathrm{Et}_{2} \mathrm{O}$ in an $\mathrm{EtOH}$ solution $(2 \mathrm{~mL})$ of $\mathbf{2 a}(80 \mathrm{mg}, 0.10 \mathrm{mmol}) \mathrm{kept}$ at $-30^{\circ} \mathrm{C}$ for 2 weeks. The crystals were highly temperature sensitive and decomposed at room temperate, which hampered isolation and precluded full characterization $\left({ }^{13} \mathrm{C} N M R\right.$ and elemental analysis) of complex 4. ${ }^{1} \mathrm{H}$ NMR $\left(400 \mathrm{MHz}, \mathrm{CD}_{3} \mathrm{CN}\right): \delta 6.92\left(\mathrm{~s}, 4 \mathrm{H}, \mathrm{H}_{\mathrm{Im}}\right), 4.24(\mathrm{~s}, 12 \mathrm{H}, \mathrm{N}-$ $\left.\mathrm{CH}_{3}\right), 3.66-3.64\left(\mathrm{~m}, 2 \mathrm{H}, \mathrm{O}-\mathrm{CH}_{2}\right), 1.62\left(\mathrm{t}, \mathrm{J}=6.7 \mathrm{~Hz}, 3 \mathrm{H}, \mathrm{CH}_{3}-\right)$. HR-MS (ESI): calcd for $\mathrm{C}_{24} \mathrm{H}_{42} \mathrm{IN}_{8} \mathrm{Ni}_{2} \mathrm{O}_{2}[\mathrm{M}-\mathrm{I}]^{+} \mathrm{m} / \mathrm{z}=717.1177$ (found 717.1179).

\section{Synthesis of 5}

Method A: Complex 2a (100 mg $0.13 \mathrm{mmol})$ and $\mathrm{NH}_{4} \mathrm{PF}_{6}(64 \mathrm{mg}, 0.39 \mathrm{mmol})$ were mixed in $\mathrm{CH}_{3} \mathrm{CN}(5 \mathrm{~mL})$ for $30 \mathrm{~min}$. All volatiles were removed in vacuo and the product extracted with $\mathrm{CH}_{2} \mathrm{Cl}_{2}$ and filtered through Celite. The volatiles were evaporated to leave the product as a dark red powder (59 mg, 45\%). Crystals of the product were grown by slow diffusion of $\mathrm{Et}_{2} \mathrm{O}$ in the $\mathrm{CH}_{2} \mathrm{Cl}_{2}$ solution.

Method B: A mixture of NaI (40 mg, $0.27 \mathrm{mmol})$ and complex 2a (100 mg, $0.13 \mathrm{mmol})$ in $\mathrm{CH}_{3} \mathrm{CN}(3 \mathrm{~mL})$ was treated with formic acid $(10 \mu \mathrm{L}, 0.27 \mathrm{mmol})$. The mixture was stirred for $5 \mathrm{~min}$. After this time, the solvent was removed in vacuo and the product extracted with $\mathrm{CH}_{2} \mathrm{Cl}_{2}$ and filtered through Celite. All volatiles were evaporated to leave the product as a dark red powder (133 mg, 98\%). 
Method C: Complex 2a (20 mg, $25 \mu \mathrm{mol})$ was dissolved in $\mathrm{CD}_{3} \mathrm{CN}(0.3 \mathrm{ml})$ in a Young's NMR Tube. Dry ice $(2 \mathrm{mg}, 125 \mu \mathrm{mol})$ or phenol $(6 \mathrm{mg}, 90 \mu \mathrm{mol})$ were added and the solution sonicated for $5 \mathrm{~min}$ and monitored by NMR until the $-\mathrm{OH}$ resonance disappeared. Formation of 5 was observed as a red precipitate within $5 \mathrm{~min}$.

${ }^{1} \mathrm{H}$ NMR (400 MHz, $\left.\mathrm{CD}_{2} \mathrm{Cl}_{2}\right): \delta 6.80\left(\mathrm{~s}, 4 \mathrm{H}, \mathrm{H}_{\mathrm{Im}}\right), 4.21\left(\mathrm{~s}, 12 \mathrm{H}, \mathrm{CH}_{3}\right) \cdot{ }^{13} \mathrm{C}\left\{{ }^{1} \mathrm{H}\right\}$ NMR $(101$ $\left.\mathrm{MHz}, \mathrm{CD}_{2} \mathrm{Cl}_{2}\right): \delta 174.90(\mathrm{C}-\mathrm{Ni}), 123.36\left(\mathrm{C}_{\mathrm{Im}} \mathrm{H}\right), 38.18\left(\mathrm{NCH}_{3}\right)$. HR-MS (ESI): calcd for $\mathrm{C}_{10} \mathrm{H}_{16} \mathrm{IN} 4 \mathrm{Ni}[\mathrm{M}-\mathrm{I}]^{+} \mathrm{m} / \mathrm{z}=376.9768$ (found 376.9767). Anal. Calcd for $\mathrm{C}_{10} \mathrm{H}_{16} \mathrm{I}_{2} \mathrm{~N}_{4} \mathrm{Ni}$ (504.77): C, 23.80; H, 3.20; N, 11.10. Found: C, 23.83; H, 3.41; N, 11.24.

\section{Synthesis of 6}

Complex 2a (100 mg, $0.13 \mathrm{mmol})$ was dissolved in $\mathrm{CH}_{3} \mathrm{CN}(3 \mathrm{~mL})$. To this solution formic acid $(0.4 \mathrm{~mL}, 0.13 \mathrm{mmol})$ and subsequently $\mathrm{K}_{2} \mathrm{CO}_{3}$ was added $(90 \mathrm{mg}, 0.65 \mathrm{mmol})$ and the reaction was stirred for $30 \mathrm{~min}$. All volatiles were subsequently evaporated and the solid dissolved in $\mathrm{CH}_{2} \mathrm{Cl}_{2}$ and filtered through Celite to leave a pale yellow solid (31 mg, 76\%). ${ }^{1} \mathrm{H}$ NMR (400 MHz, $\left.\mathrm{CD}_{2} \mathrm{Cl}_{2}\right): \delta 6.84\left(\mathrm{~s}, 4 \mathrm{H}, \mathrm{H}_{\mathrm{Im}}\right), 4.18\left(\mathrm{~s}, 12 \mathrm{H}, \mathrm{CH}_{3}\right) .{ }^{13} \mathrm{C}\left\{{ }^{1} \mathrm{H}\right\} \mathrm{NMR}(101 \mathrm{MHz}$, $\left.\mathrm{CD}_{2} \mathrm{Cl}_{2}\right): \delta 177.91(\mathrm{C}=\mathrm{O}), 166.49(\mathrm{C}-\mathrm{Ni}), 122.20\left(\mathrm{C}_{\mathrm{Im}} \mathrm{H}\right), 36.27\left(\mathrm{NCH}_{3}\right)$. HR-MS (ESI): calcd for $\mathrm{C}_{11} \mathrm{H}_{17} \mathrm{~N}_{4} \mathrm{NiO}_{3}[\mathrm{M}+\mathrm{H}]^{+} \mathrm{m} / \mathrm{z}=311.0649$ (found 311.0645). Anal. Calcd for $\mathrm{C}_{11} \mathrm{H}_{16} \mathrm{~N}_{4} \mathrm{NiO}_{3}$ (310.97): C, 42.49; H, 5.19; N, 18.87. Found: C, 42.83; H, 4.98; N, 18.95.

\section{Synthesis of 8a}

The reaction of triazolium triflate salt $7 \mathbf{a}(300 \mathrm{mg}, 0.82 \mathrm{mmol}), \mathrm{Ni}(\mathrm{OAc})_{2}\left(\mathrm{H}_{2} \mathrm{O}\right)_{4}(120 \mathrm{mg}, 0.48$ $\mathrm{mmol})$, and $\mathrm{NaH}(52 \mathrm{mg}, 2.5 \mathrm{mmol})$ in THF $(10 \mathrm{~mL})$ according to the general procedure yielded complex $8 \mathbf{a}$ as a yellow crystalline powder (122 $\mathrm{mg}, 46 \%)$.

${ }^{1} \mathrm{H}$ NMR $\left(400 \mathrm{MHz}, \mathrm{CD}_{3} \mathrm{CN}\right): \delta 8.03-8.01\left(\mathrm{~m}, 2 \mathrm{H}, \mathrm{H}_{\mathrm{Ph}}\right), 7.88-7.86\left(\mathrm{~m}, 3 \mathrm{H}, \mathrm{H}_{\mathrm{Ph}}\right), 4.34(\mathrm{~m}$, broad, $\left.2 \mathrm{H}, \mathrm{N}-\mathrm{CH}_{2}-\right), 3.72\left(\mathrm{~s}, 3 \mathrm{H}, \mathrm{N}-\mathrm{CH}_{3}\right), 1.78-1.70$ (m, $\left.2 \mathrm{H},-\mathrm{CH}_{2}-\mathrm{Et}\right), 1.38-1.29$ (m, 2H, $\left.\mathrm{CH}_{2}-\mathrm{Me}\right), 0.98$ (t, J=6 Hz, 3H, $\left.-\mathrm{CH}_{3}\right),-3.86(\mathrm{~s}, 1 \mathrm{H}, \mathrm{OH}) .{ }^{13} \mathrm{C}\left\{{ }^{1} \mathrm{H}\right\} \mathrm{NMR}\left(101 \mathrm{MHz}, \mathrm{CD}_{3} \mathrm{CN}\right)$ : $\delta 147.37(\mathrm{C}-\mathrm{Ni}), 145.48\left(\mathrm{C}_{\mathrm{Trz}}-\mathrm{N}\right), 131.61\left(\mathrm{C}_{\mathrm{Ph}}-\mathrm{H}\right), 131.43\left(\mathrm{C}_{\mathrm{Ph}}-\mathrm{H}\right), 130.30\left(\mathrm{C}_{\mathrm{Ph}}-\mathrm{H}\right), 129.69$ $\left(\mathrm{C}_{\mathrm{Ph}}-\mathrm{H}\right), 129.12\left(\mathrm{C}_{\mathrm{Ph}}-\mathrm{C}_{\mathrm{Trz}}\right), 54.51\left(\mathrm{CH}_{2}-\mathrm{N}\right), 37.73\left(\mathrm{CH}_{3}-\mathrm{N}\right), 32.21\left(\mathrm{CH}_{2}-\mathrm{CH}_{2}-\right), 20.77\left(\mathrm{CH}_{2}-\right.$ $\left.\mathrm{CH}_{3}\right), 14.06\left(-\mathrm{CH}_{3}\right)$ HR-MS (ESI): calcd for $\mathrm{C}_{53} \mathrm{H}_{70} \mathrm{~N}_{12} \mathrm{Ni}_{2} \mathrm{O}_{5} \mathrm{~F}_{3} \mathrm{~S}^{+}[\mathrm{M}-\mathrm{OTf}]^{+} \mathrm{m} / \mathrm{z}=1159.3966$ (found 1159.3957). Anal. Calcd for $\mathrm{C}_{54} \mathrm{H}_{70} \mathrm{~F}_{6} \mathrm{~N}_{6} \mathrm{Ni}_{2} \mathrm{O}_{8} \mathrm{~S}_{2}$ (1310.73): C, 49.48; H, 5.38; N, 12.82 . Found: C, 49.83; H, 5.41; N, 13.04 .

\section{Synthesis of $8 \mathrm{~b}$}

The reaction of triazolium triflate salt $7 \mathbf{b}(300 \mathrm{mg}, 0.70 \mathrm{mmol}), \mathrm{Ni}(\mathrm{OAc})_{2}\left(\mathrm{H}_{2} \mathrm{O}\right)_{4}(94 \mathrm{mg}, 0.38$ $\mathrm{mmol})$, and $\mathrm{NaH}(52 \mathrm{mg}, 2.5 \mathrm{mmol})$ in THF (10 mL) according to the general procedure yielded complex $\mathbf{8 b}$ as a yellow crystalline powder (114 $\mathrm{mg}, 42 \%)$. 
${ }^{1} \mathrm{H}$ NMR (400 MHz, CD $\left.{ }_{3} \mathrm{CN}\right): \delta 8.37\left(\mathrm{dd}, \mathrm{J}=7 \mathrm{~Hz}, \mathrm{~J}=3 \mathrm{~Hz}, 2 \mathrm{H}, \mathrm{H}_{\mathrm{Ph}}\right), 7.92-7.88\left(\mathrm{~m}, 1 \mathrm{H}, \mathrm{H}_{\mathrm{Ph}}\right)$, 7.79-7.75 (m, 3H, $\mathrm{H}_{\mathrm{Ph}}$ ), 7.39-7.33 (m, 1H, $\left.\mathrm{H}_{\mathrm{Ph}}\right), 7.14$ (s, 1H, $\mathrm{H}_{\mathrm{Mes}}$ ), 6.69 (s, 1H, $\mathrm{H}_{\mathrm{Mes}}$ ), 4.01 (s, $\left.3 \mathrm{H}, \mathrm{N}-\mathrm{CH}_{3}\right), 2.41\left(\mathrm{~s}, 3 \mathrm{H},-\mathrm{CH}_{3}\right), 1.14\left(\mathrm{~s}, 3 \mathrm{H},-\mathrm{CH}_{3}\right), 1.05\left(\mathrm{~s}, 3 \mathrm{H},-\mathrm{CH}_{3}\right),-5.45(\mathrm{~s},-\mathrm{OH}) .{ }^{13} \mathrm{C}\left\{{ }^{1} \mathrm{H}\right\}$ NMR (101 MHz, CD 3 CN): $\delta 148.32(\mathrm{C}-\mathrm{Ni}), 146.79\left(\mathrm{C}_{\mathrm{Trz}}-\mathrm{N}\right), 142.29\left(\mathrm{C}_{\mathrm{Mes}}-\mathrm{H}\right), 137.92\left(\mathrm{C}_{\mathrm{Mes}^{-}}\right.$ $\left.\mathrm{CH}_{3}\right), 136.35\left(\mathrm{C}_{\text {Mes }}-\mathrm{CH}_{3}\right), 134.41\left(\mathrm{C}_{\text {Mes }}-\mathrm{H}\right), 130.87\left(\mathrm{C}_{\text {Mes }}-\mathrm{CH}_{3}\right), 130.82\left(\mathrm{C}_{\mathrm{Ph}}-\mathrm{H}\right), 130.70\left(\mathrm{C}_{\mathrm{Ph}}-\right.$ $\mathrm{H}), 130.53\left(\mathrm{C}_{\mathrm{Ph}}-\mathrm{H}\right), 129.82\left(\mathrm{C}_{\mathrm{Ph}}-\mathrm{C}_{\mathrm{Trz}}\right), 127.23\left(\mathrm{C}_{\mathrm{Mes}}-\mathrm{N}\right), 40.11\left(\mathrm{CH}_{3}-\mathrm{N}\right), 21.45\left(-\mathrm{CH}_{3}\right), 17.90$ $\left(-\mathrm{CH}_{3}\right), 17.69\left(-\mathrm{CH}_{3}\right)$. HR-MS (ESI): calcd for $\mathrm{C}_{73} \mathrm{H}_{78} \mathrm{~F}_{3} \mathrm{~N}_{12} \mathrm{Ni}_{2} \mathrm{O}_{8} \mathrm{~S}_{2}[\mathrm{M}-\mathrm{OTf}]^{+} \mathrm{m} / \mathrm{z}=$ 1407.4592 (found 1407.4584). Anal. Calcd for $\mathrm{C}_{74} \mathrm{H}_{78} \mathrm{~F}_{6} \mathrm{~N}_{12} \mathrm{Ni}_{2} \mathrm{O}_{8} \mathrm{~S}_{2}$ (1559.01): C, 57.01; H, 5.04; N, 10.78. Found: C, 57.08; H, 5.01; N, 10.88 .

\section{Synthesis of 8c}

The reaction of triazolium triflate salt $7 \mathbf{c}(300 \mathrm{mg}, 0.77 \mathrm{mmol}), \mathrm{Ni}(\mathrm{OAc})_{2}\left(\mathrm{H}_{2} \mathrm{O}\right)_{4}(94 \mathrm{mg}, 0.38$ $\mathrm{mmol})$, and $\mathrm{NaH}(52 \mathrm{mg}, 2.5 \mathrm{mmol})$ in THF (10 $\mathrm{mL})$ according to the general procedure yielded complex as a yellow crystalline powder ( $86 \mathrm{mg}, 32 \%)$.

${ }^{1} \mathrm{H}$ NMR (400 MHz, $\mathrm{CD}_{2} \mathrm{Cl}_{2}$ ): $\delta 8.58\left(\mathrm{dd}, \mathrm{J}=7 \mathrm{~Hz}, \mathrm{~J}=3 \mathrm{~Hz}, 2 \mathrm{H}, \mathrm{H}_{\mathrm{Ph}}\right), 7.61-7.48\left(\mathrm{~m}, 6 \mathrm{H}, \mathrm{H}_{\mathrm{Ph}}\right)$, $7.32\left(\mathrm{dd}, 2 \mathrm{H}, \mathrm{H}_{\mathrm{Ph}}\right), 3.66\left(\mathrm{~s}, 3 \mathrm{H}, \mathrm{N}-\mathrm{CH}_{3}\right),-4.60(\mathrm{~s}, 1 \mathrm{H}, \mathrm{OH}) .{ }^{13} \mathrm{C}\left\{{ }^{1} \mathrm{H}\right\} \mathrm{NMR}\left(101 \mathrm{MHz}, \mathrm{CD}_{2} \mathrm{Cl}_{2}\right)$ : $\delta 146.17(\mathrm{C}-\mathrm{Ni}), 144.36\left(\mathrm{C}_{\mathrm{Tr} z}-\mathrm{N}\right), 139.34\left(\mathrm{C}_{\mathrm{Ph}}\right), 131.01\left(\mathrm{C}_{\mathrm{Ph}}\right), 130.81\left(\mathrm{C}_{\mathrm{Ph}}\right), 130.60\left(\mathrm{C}_{\mathrm{Ph}}\right)$, $129.75\left(\mathrm{C}_{\mathrm{Ph}}\right), 127.54\left(\mathrm{C}_{\mathrm{Ph}}-\mathrm{C}_{\mathrm{trz}}\right), 124.58\left(\mathrm{C}_{\mathrm{Ph}}\right), 37.89\left(\mathrm{CH}_{3}-\mathrm{N}\right)$. HR-MS (ESI): calcd for $\mathrm{C}_{30} \mathrm{H}_{27} \mathrm{~N}_{6} \mathrm{NiO}[\mathrm{M}]^{++} \mathrm{m} / \mathrm{z}=545.1594$ (found 545.1592). Anal. Calcd for $\mathrm{C}_{62} \mathrm{H}_{54} \mathrm{~F}_{6} \mathrm{~N}_{6} \mathrm{Ni}_{2} \mathrm{O}_{8} \mathrm{~S}_{2}$ (1390.68): C, 53.55; H, 3.91; N, 12.09. Found: C, 53.21; H, 4.01; N, 12.08.

\section{Synthesis of 8d}

The reaction of triazolium triflate salt $7 \mathbf{d}(300 \mathrm{mg}, 0.93 \mathrm{mmol}), \mathrm{Ni}(\mathrm{OAc})_{2}\left(\mathrm{H}_{2} \mathrm{O}\right)_{4}(150 \mathrm{mg}, 0.60$ $\mathrm{mmol})$, and $\mathrm{NaH}(58 \mathrm{mg}, 2.7 \mathrm{mmol})$ in THF $(10 \mathrm{~mL})$, according to the general procedure, yielded complex $8 \mathbf{d}$ as a yellow crystalline powder (95 $\mathrm{mg}, 36 \%$ ).

${ }^{1} \mathrm{H}$ NMR (400 MHz, CD ${ }_{3} \mathrm{CN}$ ): $\delta$ 7.78-7.75 (m, 2H, H $\left.\mathrm{Ph}_{\mathrm{Ph}}\right), 7.69-7.65$ (m, 3H, HPh), 3.94 (s, 3H, $\left.\mathrm{N}-\mathrm{CH}_{3}\right), 3.69\left(\mathrm{~N}-\mathrm{CH}_{3}\right),-2.99(-\mathrm{OH}) .{ }^{13} \mathrm{C}\left\{{ }^{1} \mathrm{H}\right\} \mathrm{NMR}\left(101 \mathrm{MHz}, \mathrm{CD}_{3} \mathrm{CN}\right): \delta 148.48(\mathrm{C}-\mathrm{Ni})$, $146.16\left(\mathrm{C}_{\mathrm{Trz}}-\mathrm{N}\right), 131.31\left(\mathrm{C}_{\mathrm{Ph}}\right), 131.22\left(\mathrm{C}_{\mathrm{Ph}}\right), 130.51\left(\mathrm{C}_{\mathrm{Ph}}\right), 130.36\left(\mathrm{C}_{\mathrm{Ph}}-\mathrm{C}_{\mathrm{trz}}\right), 130.13\left(\mathrm{C}_{\mathrm{Ph}}\right)$, $128.73\left(\mathrm{C}_{\mathrm{Ph}}\right), 41.18\left(\mathrm{CH}_{3}-\mathrm{N}\right), 37.51\left(\mathrm{CH}_{3}-\mathrm{N}\right)$. HR-MS (ESI): calcd for $\mathrm{C}_{46} \mathrm{H}_{46} \mathrm{~F}_{3} \mathrm{~N}_{12} \mathrm{Ni}_{2} \mathrm{O}_{5} \mathrm{~S}[\mathrm{M}-$ $\mathrm{OTf}^{+} \mathrm{m} / \mathrm{z}=991.2084$ (found 991.2082). Anal. Calcd for $\mathrm{C}_{47} \mathrm{H}_{46} \mathrm{~F}_{6} \mathrm{~N}_{12} \mathrm{Ni}_{2} \mathrm{O}_{8} \mathrm{~S}_{2}$ (1142.40): C, 44.16; H, 4.06; N, 14.71. Found: C, 44.22; H, 4.13; N, 14.53.

\section{Synthesis of 9a}

Complex 8a (200 mg, $0.15 \mathrm{mmol})$ and MeOTf $(0.64 \mathrm{~mL}, 0.56 \mathrm{mmol})$ in $\mathrm{CH}_{3} \mathrm{CN}(5 \mathrm{~mL})$ were stirred for $5 \mathrm{~min}$. All volatiles were evaporated and the solid was dissolved in a minimum amount of $\mathrm{CH}_{2} \mathrm{Cl}_{2}$ and precipitated with $\mathrm{Et}_{2} \mathrm{O}$ to afford $9 \mathrm{a}(150 \mathrm{mg}, 88 \%)$. 
${ }^{1} \mathrm{H}$ NMR (400 MHz, CD $\left.{ }_{3} \mathrm{CN}\right): \delta 7.76-7.74\left(\mathrm{~m}, 6 \mathrm{H}, \mathrm{H}_{\mathrm{Ph}}\right), 7.69-7.65$ (m, 4H, HPh), 3.80 (s, 6H, $\left.\mathrm{N}-\mathrm{CH}_{3}\right), 3.32$ (m, broad, 4H, N- $\left.\mathrm{CH}_{2}-\right), 3.26\left(\mathrm{~s}, 3 \mathrm{H}, \mathrm{CH}_{3} \mathrm{O}\right), 1.62-1.58\left(\mathrm{~m}, 4 \mathrm{H},-\mathrm{CH}_{2}-\mathrm{CH}_{3}\right)$, $1.32-1.28\left(\mathrm{~m}, 4 \mathrm{H}, \mathrm{CH}_{2} \mathrm{Me}\right), 0.96\left(\mathrm{t}, \mathrm{J}=6 \mathrm{~Hz}, 6 \mathrm{H},-\mathrm{CH}_{3}\right) .{ }^{13} \mathrm{C}\left\{{ }^{1} \mathrm{H}\right\} \mathrm{NMR}\left(101 \mathrm{MHz}, \mathrm{CD}_{3} \mathrm{CN}\right): \delta$ $145.01(\mathrm{C}-\mathrm{Ni}), 137.32\left(\mathrm{C}_{\mathrm{Trz}}-\mathrm{N}\right), 131.90\left(\mathrm{C}_{\mathrm{Ph}}-\mathrm{H}\right), 131.47\left(\mathrm{C}_{\mathrm{Ph}}-\mathrm{H}\right), 130.50\left(\mathrm{C}_{\mathrm{Ph}}-\mathrm{H}\right), 127.35$ $\left(\mathrm{C}_{\mathrm{Ph}}-\mathrm{H}\right), 123.42\left(\mathrm{C}_{\mathrm{Ph}}-\mathrm{C}_{\mathrm{Trz}}\right), 60.36\left(\mathrm{CH}_{3} \mathrm{O}\right), 54.51\left(\mathrm{CH}_{2}-\mathrm{N}\right), 38.04\left(\mathrm{CH}_{3}-\mathrm{N}\right), 31.87\left(\mathrm{CH}_{2}-\mathrm{CH}_{2}-\right.$ ), $20.23\left(\mathrm{CH}_{2}-\mathrm{CH}_{3}\right), 13.70\left(-\mathrm{CH}_{3}\right)$. HR-MS (ESI): calcd for $\mathrm{C}_{27} \mathrm{H}_{37} \mathrm{~N}_{6} \mathrm{NiO}\left[\mathrm{M}-(\mathrm{OTf})_{2}\right]^{++} \mathrm{m} / \mathrm{z}=$ 519.2377 (found 519.2376). Anal. Calcd for $\mathrm{C}_{56} \mathrm{H}_{74} \mathrm{~F}_{6} \mathrm{~N}_{12} \mathrm{Ni}_{2} \mathrm{O}_{8} \mathrm{~S}_{2}$ (1338.78): C, 50.24; H, 5.57; $\mathrm{N}, 12.56$. Found: C, 50.12; H, 5.45; N, 12.52.

\section{Synthesis of $9 \mathrm{~b}$}

Complex 8b (250 mg, $0.16 \mathrm{mmol})$ and $\mathrm{MeOTf}(0.64 \mathrm{~mL}, 0.56 \mathrm{mmol})$ in $\mathrm{CH}_{3} \mathrm{CN}(5 \mathrm{~mL})$ were stirred for $5 \mathrm{~min}$. All volatiles were evaporated, and the residual solid was dissolved in a minimum amount of $\mathrm{CH}_{2} \mathrm{Cl}_{2}$ and precipitated by the addition of $\mathrm{Et}_{2} \mathrm{O}$ to give complex $\mathbf{9 b}$ (240 $\mathrm{mg}, 94 \%)$.

${ }^{1} \mathrm{H}$ NMR (400 MHz, $\mathrm{CD}_{3} \mathrm{CN}$ ): $\delta 7.82-7.72\left(\mathrm{~m}, 10 \mathrm{H}, \mathrm{H}_{\mathrm{Ph}}\right), 7.20$ (s, 4H, Hes), 4.00 (s, 6H, N$\left.\mathrm{CH}_{3}\right), 3.23\left(\mathrm{~s}, 3 \mathrm{H}, \mathrm{CH}_{3} \mathrm{O}\right), 2.55\left(\mathrm{~s}, 6 \mathrm{H},-\mathrm{CH}_{3}\right), 1.89$ (s, 6H, $\left.-\mathrm{CH}_{3}\right) .{ }^{13} \mathrm{C}\left\{{ }^{1} \mathrm{H}\right\} \mathrm{NMR}(101 \mathrm{MHz}$, $\left.\mathrm{CD}_{3} \mathrm{CN}\right): \delta 147.60(\mathrm{C}-\mathrm{Ni}), 145.43\left(\mathrm{C}_{\mathrm{Trz}}-\mathrm{N}\right), 142.28\left(\mathrm{C}_{\mathrm{Mes}}-\mathrm{H}\right), 135.52\left(\mathrm{C}_{\mathrm{Mes}}-\mathrm{CH}_{3}\right), 135.15$ $\left(\mathrm{C}_{\text {Mes }}-\mathrm{CH}_{3}\right), 131.63\left(\mathrm{C}_{\text {Mes }}-\mathrm{H}\right), 131.48\left(\mathrm{C}_{\mathrm{Mes}}-\mathrm{CH}_{3}\right), 131.08\left(\mathrm{C}_{\mathrm{Ph}}-\mathrm{H}\right), 130.76\left(\mathrm{C}_{\mathrm{Ph}}-\mathrm{H}\right), 130.49$ $\left(\mathrm{C}_{\mathrm{Ph}}-\mathrm{H}\right), 127.34\left(\mathrm{C}_{\mathrm{Ph}}-\mathrm{C}_{\mathrm{Trz}}\right), 123.32\left(\mathrm{C}_{\mathrm{Mes}}-\mathrm{N}\right), 61.32\left(\mathrm{CH}_{3} \mathrm{O}\right), 38.43\left(\mathrm{CH}_{3}-\mathrm{N}\right), 21.35\left(-\mathrm{CH}_{3}\right)$, $17.73\left(-\mathrm{CH}_{3}\right)$. HR-MS (ESI): calcd for $\mathrm{C}_{37} \mathrm{H}_{41} \mathrm{~N}_{6} \mathrm{NiO}\left[\mathrm{M}-(\mathrm{OTf})_{2}\right]^{++} \mathrm{m} / \mathrm{z}=643.2690$ (found 643.2689). Anal. Calcd for $\mathrm{C}_{76} \mathrm{H}_{82} \mathrm{~F}_{6} \mathrm{~N}_{12} \mathrm{Ni}_{2} \mathrm{O}_{8} \mathrm{~S}_{2}$ (1584.44): C, 57.52; H, 5.21; N, 10.59. Found: C, $57.41 ; \mathrm{H}, 5.25 ; \mathrm{N}, 10.56$.

\section{Synthesis of 10}

Complex 8a (25 mg, $20 \mu \mathrm{mol})$ was dissolved in $\mathrm{CD}_{3} \mathrm{CN}(0.3 \mathrm{~mL})$ in an NMR tube. A solution of $\mathrm{HPF}_{6}\left(16 \mu \mathrm{L}, 55 \%\right.$ wt in $\left.\mathrm{H}_{2} \mathrm{O}, 90 \mu \mathrm{mol}\right)$ was added and the reaction was monitored by NMR spectroscopy over time. The reaction showed quantitative conversion to complex $\mathbf{1 0}$ and triazolium salt 7a in $2 \mathrm{~min}$, in roughly 1:1 ratio. The amount of salt $7 \mathbf{a}$ increased over time, reaching $87 \%$ in respect to complex $\mathbf{8 a}$ after 3 days. The complex was purified by precipitation with Et2O $(3 \times 5 \mathrm{~mL})$ and NMR characterization experiments were run within $8 \mathrm{~h}$ from the addition of the reagents.

${ }^{1} \mathrm{H}$ NMR (400 MHz, $\left.\mathrm{CD}_{3} \mathrm{CN}\right): \delta 7.77-7.75\left(\mathrm{~m}, 6 \mathrm{H}, \mathrm{H}_{\mathrm{Ph}}\right), 7.67-7.64\left(\mathrm{~m}, 4 \mathrm{H}, \mathrm{H}_{\mathrm{Ph}}\right), 4.31$ (s, broad,

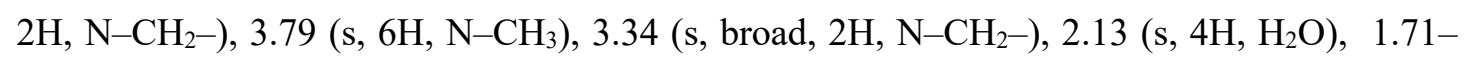
$1.61\left(\mathrm{~m}, 4 \mathrm{H},-\mathrm{CH}_{2}-\mathrm{CH}_{3}\right), 1.34-1.26\left(\mathrm{~m}, 4 \mathrm{H}, \mathrm{CH}_{2}-\mathrm{Me}\right), 0.96\left(\mathrm{t}, \mathrm{J}=6 \mathrm{~Hz}, 6 \mathrm{H},-\mathrm{CH}_{3}\right) .{ }^{13} \mathrm{C}\left\{{ }^{1} \mathrm{H}\right\}$ NMR (101 MHz, CD $\left.{ }_{3} \mathrm{CN}\right): \delta 144.85(\mathrm{C}-\mathrm{Ni}), 137.22\left(\mathrm{C}_{\mathrm{Trz}}-\mathrm{N}\right), 131.82\left(\mathrm{C}_{\mathrm{Ph}}-\mathrm{H}\right), 131.24\left(\mathrm{C}_{\mathrm{Ph}}-\right.$ $\mathrm{H}), 130.40\left(\mathrm{C}_{\mathrm{Ph}}-\mathrm{H}\right), 127.14\left(\mathrm{C}_{\mathrm{Ph}}-\mathrm{C}_{\mathrm{Trz}}\right), 54.35\left(\mathrm{CH}_{2}-\mathrm{N}\right), 37.86\left(\mathrm{CH}_{3}-\mathrm{N}\right), 31.74\left(\mathrm{CH}_{2}-\mathrm{CH}_{2}-\right)$, 
$20.08\left(\mathrm{CH}_{2}-\mathrm{CH}_{3}\right), 13.56\left(-\mathrm{CH}_{3}\right)$. HR-MS (ESI): calcd for $\mathrm{C}_{26} \mathrm{H}_{38} \mathrm{~F}_{6} \mathrm{~N}_{6} \mathrm{NiO}_{2} \mathrm{P}\left[\mathrm{M}-\mathrm{PF}_{6}\right]^{+} \mathrm{m} / \mathrm{z}=$ 669.2046 (found 669.2042).

\section{Synthesis of 11}

Complex 8a (160 mg, $0.12 \mathrm{mmol})$ and $\mathrm{NaI}(20 \mathrm{mg}, 0.13 \mathrm{mmol})$ were dissolved in $\mathrm{CH}_{3} \mathrm{CN}$ (3 $\mathrm{mL})$. Acetic acid $(16 \mu \mathrm{L}, 0.28 \mathrm{mmol})$ was added and the reaction was stirred for $30 \mathrm{~min}$. The volatiles were evaporated and the solid dissolved in $\mathrm{CH}_{2} \mathrm{Cl}_{2}$ and filtered through Celite to leave a mixture of anti- and syn-11 as a dark purple solid (88 mg, 96\%, 72:28 anti:syn).

anti-11 ${ }^{1} \mathrm{H}$ NMR (400 MHz, $\mathrm{CD}_{2} \mathrm{Cl}_{2}$ ): $\delta 8.14$ (d, J=8 Hz, 2H, $\left.\mathrm{H}_{\mathrm{Ph}}\right), 7.67-7.58$ (m, 3H, $\mathrm{H}_{\mathrm{Ph}}$ ), 4.89 (t, J= 7.6 Hz, N-CH $\mathrm{CH}_{2}, 3.81$ (s, 3H, $\left.\mathrm{CH}_{3}\right), 2.21-2.12$ (m, 2H, $\left.\mathrm{CH}_{2}-\mathrm{Et}\right), 1.59-1.35$ (m, 2H, $\left.\mathrm{CH}_{2} \mathrm{Me}\right), 0.96\left(\mathrm{t}, \mathrm{J}=7.5 \mathrm{~Hz}, 3 \mathrm{H}, \mathrm{CH}_{3}\right) . \delta 144.35(\mathrm{C}-\mathrm{Ni}), 131.07\left(\mathrm{C}_{\mathrm{Ph}}\right), 129.71\left(\mathrm{C}_{\mathrm{Ph}}\right), 129.32$ $\left(\mathrm{C}_{\mathrm{Ph}}\right), 129.00\left(\mathrm{C}_{\mathrm{Ph}}\right), 55.34\left(\mathrm{~N}-\mathrm{CH}_{2}-\mathrm{Pr}\right), 37.24\left(\mathrm{NCH}_{3}\right), 31.35\left(\mathrm{CH}_{2} \mathrm{Et}\right), 20.50\left(\mathrm{CH}_{2} \mathrm{Me}\right), 14.06$ $\left(\mathrm{CH}_{3}\right)$.

syn-11 ${ }^{1} \mathrm{H}$ NMR (400 MHz, $\left.\mathrm{CD}_{2} \mathrm{Cl}_{2}\right): \delta 7.93\left(\mathrm{~d}, \mathrm{~J}=8 \mathrm{~Hz}, 2 \mathrm{H}, \mathrm{H}_{\mathrm{Ph}}\right), 7.51\left(\mathrm{~d}, \mathrm{~J}=8 \mathrm{~Hz}, 1 \mathrm{H}, \mathrm{H}_{\mathrm{Ph}}\right)$, $7.42\left(\mathrm{t}, \mathrm{J}=8 \mathrm{~Hz}, 2 \mathrm{H}, \mathrm{H}_{\mathrm{Ph}}\right), 5.23\left(\mathrm{t}, \mathrm{J}=7.6 \mathrm{~Hz}, \mathrm{~N}-\mathrm{CH}_{2}\right), 3.78\left(\mathrm{~s}, 3 \mathrm{H}, \mathrm{CH}_{3}\right), 2.48-2.43(\mathrm{~m}, 2 \mathrm{H}$, $\mathrm{CH}_{2}-\mathrm{Et}$ ), $1.62-1.57$ (m, 2H, $\left.\mathrm{CH}_{2} \mathrm{Me}\right), 1.10$ (t, J = 7.5 Hz, 3H, $\left.\mathrm{CH}_{3}\right) . \delta 144.46(\mathrm{C}-\mathrm{Ni}), 130.67$ $\left(\mathrm{C}_{\mathrm{Ph}}\right), 130.37\left(\mathrm{C}_{\mathrm{Ph}}\right), 129.89\left(\mathrm{C}_{\mathrm{Ph}}\right), 129.16\left(\mathrm{C}_{\mathrm{Ph}}\right), 55.73\left(\mathrm{~N}-\mathrm{CH}_{2}-\mathrm{Pr}\right), 37.41\left(\mathrm{NCH}_{3}\right), 31.57$ $\left(\mathrm{CH}_{2} \mathrm{Et}\right), 20.76\left(\mathrm{CH}_{2} \mathrm{Me}\right), 14.12\left(\mathrm{CH}_{3}\right)$. HR-MS (ESI): calcd for $\mathrm{C}_{26} \mathrm{H}_{34} \mathrm{IN} \mathrm{N}_{4} \mathrm{Ni}[\mathrm{M}-\mathrm{I}]^{+} \mathrm{m} / \mathrm{z}=$ 615.1238 (found 615.1236). Anal. Calcd for $\mathrm{C}_{26} \mathrm{H}_{34} \mathrm{I}_{2} \mathrm{~N}_{6} \mathrm{Ni}$ (743.10): C, 42.02; H, 4.61; N, 11.31. Found: C, 42.07; H, 4.63; N, 11.10 .

\section{Synthesis of 12}

Complex 8a (100 mg, $76 \mu \mathrm{mol})$ was dissolved in $\mathrm{CH}_{3} \mathrm{CN}(3 \mathrm{~mL})$. Acetic acid $(16 \mu \mathrm{L}, 0.28$ mmol) was added and the reaction was stirred for $30 \mathrm{~min}$. The volatiles were evaporated and the solid was dissolved in $\mathrm{CH}_{2} \mathrm{Cl}_{2}$ and filtered through Celite. The solvent was removed to give the title product a pale yellow solid (40 $\mathrm{mg}, 92 \%$ ).

${ }^{1} \mathrm{H}$ NMR (400 MHz, $\left.\mathrm{CD}_{3} \mathrm{CN}\right): \delta 7.75-7.64\left(\mathrm{~m}, 10 \mathrm{H}, \mathrm{H}_{\mathrm{Ph}}\right), 4.57$ (m, broad, 4H, N-CH $\mathrm{CH}_{2}$ ), 3.72 (s, 6H, N-CH $), 2.14$ (s, 3H, $\left.\mathrm{CH}_{3}\right), 1.71-1.61$ (m, 4H, $\left.-\mathrm{CH}_{2}-\mathrm{CH}_{3}\right), 1.40-1.33$ (m, 4H, $\mathrm{CH}_{2}-$ $\mathrm{Me}), 0.97\left(\mathrm{t}, \mathrm{J}=6 \mathrm{~Hz}, 6 \mathrm{H},-\mathrm{CH}_{3}\right) .{ }^{13} \mathrm{C}\left\{{ }^{1} \mathrm{H}\right\} \mathrm{NMR}\left(101 \mathrm{MHz}, \mathrm{CD}_{3} \mathrm{CN}\right): \delta 171.68(\mathrm{C}-\mathrm{O}), 145.19$ $(\mathrm{C}-\mathrm{Ni}), 132.64\left(\mathrm{C}_{\mathrm{Trz}}-\mathrm{N}\right), 131.33\left(\mathrm{C}_{\mathrm{Ph}}-\mathrm{H}\right), 130.24\left(\mathrm{C}_{\mathrm{Ph}}-\mathrm{H}\right), 129.10\left(\mathrm{C}_{\mathrm{Ph}}-\mathrm{H}\right), 127.75\left(\mathrm{C}_{\mathrm{Ph}}-\mathrm{C}_{\mathrm{Trz}}\right)$, $54.48\left(\mathrm{CH}_{2}-\mathrm{N}\right), 37.86\left(\mathrm{CH}_{3}-\mathrm{N}\right), 32.03\left(\mathrm{CH}_{2}-\mathrm{CH}_{2}-\right), 30.80\left(-\mathrm{CH}_{3}\right), 20.35\left(\mathrm{CH}_{2}-\mathrm{CH}_{3}\right), 13.77$ $\left(-\mathrm{CH}_{3}\right)$. HR-MS (ESI): calcd for $\mathrm{C}_{28} \mathrm{H}_{37} \mathrm{~N}_{6} \mathrm{NiO}_{2}[\mathrm{M}-\mathrm{OTf}]^{+} \mathrm{m} / \mathrm{z}=547.2326$ (found 547.2304). Anal. Calcd for $\mathrm{C}_{29} \mathrm{H}_{37} \mathrm{~F}_{3} \mathrm{~N}_{6} \mathrm{NiO}_{5} \mathrm{~S}$ (697.40): C, 49.95; H, 5.35; N, 12.05. Found: C, 49.97; H, $5.10 ; \mathrm{N}, 12.49$. 


\section{Crystal structure determinations}

Suitable crystals of complexes $\mathbf{2 - 6 , 8}, \mathbf{8}$, and $\mathbf{1 1}$ were mounted in air at ambient conditions and measured on an Oxford Diffraction SuperNova area-detector diffractometer at $T=173(2) \mathrm{K}$ by using mirror optics monochromated $\mathrm{Mo}_{\mathrm{K} \alpha}$ radiation $(\lambda=0.71073 \AA)$ and $\mathrm{Al}$ filtered. ${ }^{44}$ Data reduction was performed by using the CrysAlisPro program. ${ }^{45}$ The intensities were corrected for Lorentz and polarization effects, and an absorption correction based on the multi-scan method by using SCALE3 ABSPACK in CrysAlisPro was applied. The structures were solved by direct methods by using SHELXT, and all non-hydrogen atoms were refined anisotropically. ${ }^{46}$

All hydrogen atoms were placed in geometrically calculated positions and refined by using a riding model with each hydrogen atom assigned a fixed isotropic displacement parameter (1.2 Ueq of its parent atom, 1.5 Ueq for the methyl groups). Structures were refined on $F^{2}$ by using full-matrix least-squares procedures. The weighting schemes were based on counting statistics and included a factor to downweight the intense reflections. All calculations were performed by using the SHELXL-2014 program. ${ }^{47}$ Further crystallographic details are compiled in Tables S1-S12. Crystallographic data for all structures have been deposited with the Cambridge Crystallographic Data Centre (CCDC) as supplementary publication numbers 2016160 (2a), 2016161 (2b), 2016162 (2c), 2016163 (3a), 2016164 (3b), 2017645 (3c), 2016165 (4), 2016166 (5), 2016167 (6), 2016168 (8a), 2016169 (8d), 2016170 (11).

\section{ASSOCIATED CONTENT}

Supporting Information. NMR spectra, selected IR spectra, buried volume calculation details, crystallographic and HR-MS data.

Declaration of competing financial interests: The authors declare no competing financial interests.

\section{AUTHOR INFORMATION}

\section{Corresponding Author}

Martin Albrecht, Department of Chemistry and Biochemistry, University of Bern, Freiestrasse 3, CH-3012 Bern, Switzerland, martin.albrecht@dcb.unibe.ch.

Author Contributions. The manuscript was written through contributions of all authors. 
We acknowledge generous financial support from the European Research Council (CoG 615653), from the the Marie Curie ITN NoNoMeCat (grant 675020-MSCA-ITN-2015-ETN), and from the Swiss National Science Foundation (200020_182663). We thank the group of Chemical Crystallography of the University of Bern for X-ray analysis of all reported structures.

\section{References}

(1) Hikichi, S.; Yoshizawa, M.; Sasakura, Y.; Akita, M.; Moro-oka, Y. First Synthesis and Structural Characterization of Dinuclear M(III) Bis( $\mu$-Oxo) Complexes of Nickel and Cobalt with Hydrotris(Pyrazolyl)Borate Ligand. J. Am. Chem. Soc. 1998, 120, 1056710568 .

(2) Poyatos, M.; Mata, J. A.; Peris, E. Complexes with Poly(N-Heterocyclic Carbene) Ligands: Structural Features and Catalytic Applications. Chem. Rev. 2009, 109, 36773707.

(3) Mejuto, C.; García-Eleno, M. A.; Guisado-Barrios, G.; Spasyuk, D.; Gusev, D.; Peris, E. Ruthenium Complexes with an N-Heterocyclic Carbene NNC-Pincer Ligand: Preparation and Catalytic Properties. Org. Chem. Front. 2015, 2, 936-941.

(4) Company, A.; Gómez, L.; Mas-Ballesté, R.; Korendovych, I. V.; Ribas, X.; Poater, A.; Parella, T.; Fontrodona, X.; Benet-Buchholz, J.; Solà, M.; Que, L.; Rybak-Akimova, E. V.; Costas, M. Fast $\mathrm{O}_{2}$ Binding at Dicopper Complexes Containing Schiff-Base Dinucleating Ligands. Inorg. Chem. 2007, 46, 4997-5012.

(5) Schmidt, J. A. R.; Lobkovsky, E. B.; Coates, G. W. Chromium(III) Octaethylporphyrinato Tetracarbonylcobaltate: A Highly Active, Selective, and Versatile Catalyst for Epoxide Carbonylation. J. Am. Chem. Soc. 2005, 127, 1142611435 .

(6) Tsutsumi, H.; Sunada, Y.; Shiota, Y.; Yoshizawa, K.; Nagashima, H. Nickel(II), Palladium(II), and Platinum(II) $\eta^{3}$-Allyl Complexes Bearing a Bidentate Titanium(IV) Phosphinoamide Ligand: A Ti $\leftarrow \mathrm{M}_{2}$ Dative Bond Enhances the Electrophilicity of the

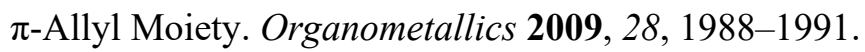

(7) Zhou, W.; Napoline, J. W.; Thomas, C. M. A Catalytic Application of Co/Zr 
Heterobimetallic Complexes: Kumada Coupling of Unactivated Alkyl Halides with Alkyl Grignard Reagents. Eur. J. Inorg. Chem. 2011, 2011, 2029-2033.

(8) Banerjee, S.; Karunananda, M. K.; Bagherzadeh, S.; Jayarathne, U.; Parmelee, S. R.; Waldhart, G. W.; Mankad, N. P. Synthesis and Characterization of Heterobimetallic Complexes with Direct $\mathrm{Cu}-\mathrm{M}$ Bonds $(\mathrm{M}=\mathrm{Cr}, \mathrm{Mn}, \mathrm{Co}, \mathrm{Mo}, \mathrm{Ru}, \mathrm{W})$ Supported by $\mathrm{N}$ Heterocyclic Carbene Ligands: A Toolkit for Catalytic Reaction Discovery. Inorg. Chem. 2014, 53, 11307-11315.

(9) Pal, S.; Uyeda, C. Evaluating the Effect of Catalyst Nuclearity in Ni-Catalyzed Alkyne Cyclotrimerizations. J. Am. Chem. Soc. 2015, 137, 8042-8045.

(10) Schuster, O.; Yang, L.; Raubenheimer, H. G.; Albrecht, M. Beyond Conventional N Heterocyclic Carbenes: Abnormal, Remote, and Other Classes of NHC Ligands with Reduced Heteroatom Stabilization. Chem. Rev. 2009, 109, 3445-3478.

(11) Krüger, A.; Albrecht, M. Abnormal N-Heterocyclic Carbenes: More than Just Exceptionally Strong Donor Ligands. Aust. J. Chem. 2011, 64, 1113-1117.

(12) Martin, D.; Melaimi, M.; Soleilhavoup, M.; Bertrand, G. A Brief Survey of Our Contribution to Stable Carbene Chemistry. Organometallics 2011, 30, 5304-5313.

(13) Donnelly, K. F.; Petronilho, A.; Albrecht, M. Application of 1,2,3-Triazolylidenes as Versatile NHC-Type Ligands: Synthesis, Properties, and Application in Catalysis and Beyond. Chem. Commun. 2013, 49, 1145-1159.

(14) Crabtree, R. H. Abnormal, Mesoionic and Remote N-Heterocyclic Carbene Complexes. Coord. Chem. Rev. 2013, 257, 755-766.

(15) Vivancos, Á.; Segarra, C.; Albrecht, M. Mesoionic and Related Less HeteroatomStabilized N-Heterocyclic Carbene Complexes: Synthesis, Catalysis, and Other Applications. Chem. Rev. 2018, 118, 9493-9586.

(16) Dible, B. R.; Sigman, M. S.; Arif, A. M. Oxygen-Induced Ligand Dehydrogenation of a Planar Bis- $\mu$-Chloronickel(I) Dimer Featuring an NHC Ligand. Inorg. Chem. 2005, 44, 3774-3776.

(17) Schaub, T.; Radius, U. Efficient C-F and C-C Activation by a Novel N-Heterocyclic Carbene-Nickel(0) Complex. Chem. Eur. J. 2005, 11, 5024-5030.

(18) Lee, C. H.; Laitar, D. S.; Mueller, P.; Sadighi, J. P. Generation of a Doubly Bridging $\mathrm{CO}_{2}$ Ligand and Deoxygenation of $\mathrm{CO}_{2}$ by an (NHC)Ni(0) Complex. J. Am. Chem. Soc. 2007, 129, 13802-13803. 
(19) Zarzycki, B.; Zell, T.; Schmidt, D.; Radius, U. $\mathrm{P}_{4}$ Activation at $\mathrm{Ni}^{0}$ : Selective Formation of an NHC-Stabilized, Dinuclear Nickel Complex $\left[\mathrm{Ni}_{2}\left(\mathrm{iPr}_{2} \operatorname{Im}\right)_{4}\left(\mu, \eta^{2: 2}-\mathrm{P}_{2}\right)\right]$. Eur. J. Inorg. Chem. 2013, 2051-2058.

(20) Hoshimoto, Y.; Hayashi, Y.; Suzuki, H.; Ohashi, M.; Ogoshi, S. One-Pot, Single-Step, and Gram-Scale Synthesis of Mononuclear [ $\left(\eta^{6}-\right.$ Arene)Ni(N-Heterocyclic Carbene)] Complexes: Useful Precursors of the $\mathrm{Ni}^{0}-\mathrm{NHC}$ Unit. Organometallics 2014, 33, 1276 1282.

(21) Kitajima, N.; Hikichi, S.; Tanaka, M.; Morooka, Y. Fixation of Atmospheric Carbon Dioxide by a Series of Hydroxo Complexes of Divalent Metal Ions and the Implication for the Catalytic Role of Metal Ion in Carbonic Anhydrase. Synthesis, Characterization, and Molecular Structure of $[\mathrm{LM}(\mathrm{OH})]_{\mathrm{n}}(\mathrm{n}=1$ or 2$)$ and $\mathrm{LM}\left(\mu-\mathrm{CO}_{3}\right) \mathrm{ML}(\mathrm{M}(\mathrm{II})=\mathrm{Mn}$, Fe, Co, Ni, Cu, Zn; L = HB(3,5-iso-Pr 2 pz) $)_{3}$. J. Am. Chem. Soc. 1993, 115, 5496-5508.

(22) Jonasson, K. J.; Mousa, A. H.; Wendt, O. F. Synthesis and Characterisation of $\mathrm{POC}_{\mathrm{sp} 3} \mathrm{OP}$ Supported Ni(II) Hydroxo, Hydroxycarbonyl and Carbonate Complexes. Polyhedron 2018, 143, 132-137.

(23) Barrios, A. M.; Lippard, S. J. Interaction of Urea with a Hydroxide-Bridged Dinuclear Nickel Center: An Alternative Model for the Mechanism of Urease. J. Am. Chem. Soc. 2000, 122, 9172-9177.

(24) Benini, S.; Rypniewski, W. R.; Wilson, K. S.; Miletti, S.; Ciurli, S.; Mangani, S. A New Proposal for Urease Mechanism Based on the Crystal Structures of the Native and Inhibited Enzyme from Bacillus Pasteurii: Why Urea Hydrolysis Costs Two Nickels. Structure 1999, 7, 205-216.

(25) Dible, B. R.; Sigman, M. S. Unusual Reactivity of Molecular Oxygen with $\pi$ Allylnickel(N-Heterocyclic Carbene) Chloride Complexes. J. Am. Chem. Soc. 2003, $125,872-873$.

(26) Carmona, E.; Marin, J. M.; Palma, P.; Paneque, M.; Poveda, M. L. Pyrrolyl, Hydroxo, and Carbonate Organometallic Derivatives of Nickel(II). Crystal and Molecular Structure of $\left[\mathrm{Ni}\left(\mathrm{CH}_{2} \mathrm{C}_{6} \mathrm{H}_{4}-\mathrm{O}-\mathrm{Me}\right)\left(\mathrm{PMe}_{3}\right)(\mu-\mathrm{OH})\right]_{2} \cdot 2,5-\mathrm{HNC}_{4} \mathrm{H}_{2} \mathrm{Me}_{2}$. Inorg. Chem. 1989, 28, 1895-1900.

(27) Huang, D.; Holm, R. H. Reactions of the Terminal Ni ${ }^{\text {II }}-\mathrm{OH}$ Group in Substitution and Electrophilic Reactions with Carbon Dioxide and Other Substrates: Structural Definition of Binding Modes in an Intramolecular $\mathrm{Ni}^{\mathrm{II}} \cdots \mathrm{Fe}^{\mathrm{II}}$ Bridged Site. J. Am. Chem. Soc. 2010, 132, 4693-4701. 
(28) Fong, H.; Moret, M.-E.; Lee, Y.; Peters, J. C. Heterolytic $\mathrm{H}_{2}$ Cleavage and Catalytic Hydrogenation by an Iron Metallaboratrane. Organometallics 2013, 32, 3053-3062.

(29) Yao, C.; Chakraborty, P.; Aresu, E.; Li, H.; Guan, C.; Zhou, C.; Liang, L.-C.; Huang, K.-W. Monomeric Nickel Hydroxide Stabilized by a Sterically Demanding Phosphorus-Nitrogen PN ${ }^{3}$ P-Pincer Ligand: Synthesis, Reactivity and Catalysis. Dalton Trans. 2018, 47, 16057-16065.

(30) Samantaray, M. K.; Shaikh, M. M.; Ghosh, P. Rare $\left[(\mathrm{NHC})_{2} \mathrm{Ni}-\mathrm{OH}\right]-\mathrm{Type}$ Terminal Nickel Hydroxo and [(NHC) $)_{2}$ Ni]-Type Complexes of N/O-Functionalized NHeterocyclic Carbenes as Precatalysts for Highly Desirable Base-Free Michael Reactions in Air at Ambient Temperature. Organometallics 2009, 28, 2267-2275.

(31) Herrmann, W. A.; Gerstberger, G.; Spiegler, M. Nickel(II) Complexes of NHeterocyclic Carbenes. Organometallics 1997, 16, 2209-2212.

(32) Berding, J.; Lutz, M.; Spek, A. L.; Bouwman, E. Nickel N-Heterocyclic Carbene Complexes in the Vinyl Polymerization of Norbornene. Appl. Organomet. Chem. 2011, $25,76-81$.

(33) Poater, A.; Cosenza, B.; Correa, A.; Giudice, S.; Ragone, F.; Scarano, V.; Cavallo, L. SambVca: A Web Application for the Calculation of the Buried Volume of NHeterocyclic Carbene Ligands. Eur. J. Inorg. Chem. 2009, 1759-1766.

(34) McGuinness, D. S.; Green, M. J.; Cavell, K. J.; Skelton, B. W.; White, A. H. Synthesis and Reaction Chemistry of Mixed Ligand Methylpalladium-Carbene Complexes. $J$. Organomet. Chem. 1998, 565, 165-178.

(35) McGuinness, D. S.; Cavell, K. J. Donor-Functionalized Heterocyclic Carbene Complexes of Palladium(II): Efficient Catalysts for $\mathrm{C}-\mathrm{C}$ Coupling Reactions. Organometallics 2000, 19, 741-748.

(36) Fooladi, E.; Dalhus, B.; Tilset, M. Synthesis and Characterization of Half-Sandwich NHeterocyclic Carbene Complexes of Cobalt and Rhodium. Dalton Trans. 2004, 22, 3909-3917.

(37) Huang, Y.-P.; Tsai, C.-C.; Shih, W.-C.; Chang, Y.-C.; Lin, S.-T.; Yap, G. P. A.; Chao, I.; Ong, T.-G. Kinetic and Thermodynamic Study of Syn-Anti Isomerization of Nickel Complexes Bearing Amino-Linked N-Heterocyclic Carbene Ligands: The Effect of the Pendant Arm of the NHC. Organometallics 2009, 28, 4316-4323.

(38) Hameury, S.; de Frémont, P.; Breuil, P.-A. R.; Olivier-Bourbigou, H.; Braunstein, P. 
Bis(Ether-Functionalized NHC) Nickel(II) Complexes, Trans to Cis Isomerization Triggered by Water Coordination, and Catalytic Ethylene Oligomerization. Organometallics 2015, 34, 2183-2201.

(39) Gardner, S.; Kawamoto, T.; Curran, D. P. Synthesis of 1,3-Dialkylimidazol-2-Ylidene Boranes from 1,3-Dialkylimidazolium Iodides and Sodium Borohydride. J. Org. Chem. 2015, 80, 9794-9797.

(40) Das, B.; Ravikanth, B.; Kumar, A. S.; Kanth, B. S. An Efficient Procedure for the Synthesis of Substituted Pyridines Using KF· $\mathrm{Al}_{2} \mathrm{O}_{3}$. J. Heterocycl. Chem. 2009, 46, $1208-1212$.

(41) Starikova, O. V; Dolgushin, G. V; Larina, L. I.; Ushakov, P. E.; Komarova, T. N.; Lopyrev, V. A. Synthesis of 1,3-Dialkylimidazolium and 1,3-Dialkylbenzimidazolium Salts. Russ. J. Org. Chem. 2003, 39, 1467-1470.

(42) Wei, Y.; Petronilho, A.; Mueller-Bunz, H.; Albrecht, M. Mesoionic Triazolylidene Nickel Complexes: Synthesis, Ligand Lability, and Catalytic C-C Bond Formation Activity. Organometallics 2014, 33, 5834-5844.

(43) Canseco-Gonzalez, D.; Gniewek, A.; Szulmanowicz, M.; Müller-Bunz, H.; Trzeciak, A. M.; Albrecht, M. PEPPSI-Type Palladium Complexes Containing Basic 1,2,3Triazolylidene Ligands and Their Role in Suzuki-Miyaura Catalysis. Chem. Eur. J. 2012, 18, 6055-6062.

(44) Johnson, C.; Albrecht, M. Triazolylidene Iron(II) Piano-Stool Complexes: Synthesis and Catalytic Hydrosilylation of Carbonyl Compounds. Organometallics 2017, 36, 2902-2913.

(45) Macchi, P.; Bürgi, H.-B.; Chimpri, A. S.; Hauser, J.; Gál, Z. Low-Energy Contamination of Mo Microsource X-Ray Radiation: Analysis and Solution of the Problem. J. Appl. Crystallogr. 2011, 44, 763-771.

(46) Sheldrick, G. M. SHELXT - Integrated Space-Group and Crystal-Structure Determination. Acta Crystallogr. A 2015, 71, 3-8.

(47) Sheldrick, G. M. Crystal Structure Refinement with SHELXL. Acta Crystallogr. C 2015, 71, 3-8. 


\section{Table of contents entry}

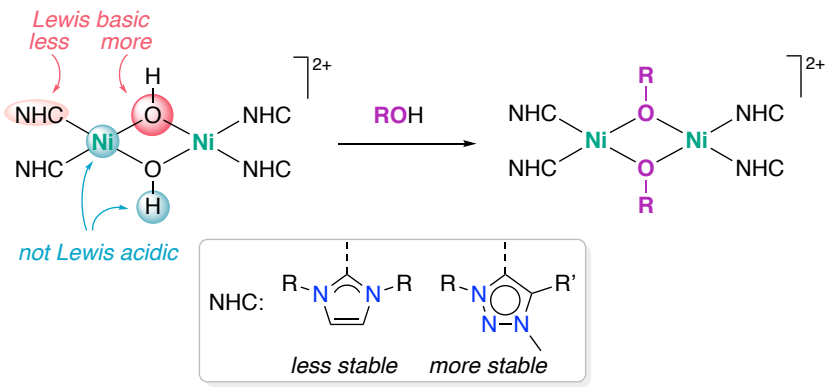

